Universidad de Talca - Facultad de Ciencias Jurídicas y Sociales

Los supuestos y el alcance de la indemnización de daños como medio de tutela precontractualen el Código Civil chileno y su eventual confluencia con la indemnización por incumplimiento contractual Patricia Verónica López Díaz

Trabajo recibido el 9 de mayo de 2016 y aprobado el 23 de enero de 2017

\title{
Los supuestos y el alcance de la indemnización de daños como medio de tutela precontractual en el Código Civil chileno y su eventual confluencia con la indemnización por incumplimiento contractual
}

\author{
Cases and scope of damage Compensation as a PRE-CONTRACtual \\ Remedy in the Chilean Civil Code and its eVentual confluence \\ WITH COMPENSATION FOR BREACH OF CONTRACT
}

Patricia Verónica López Díaz*

\begin{abstract}
RESUMEN
El presente trabajo tiene por finalidad abordar la indemnización como medio de tutela precontractual, sistematizando las distintas hipótesis en que ella procede como complementaria a la nulidad o en forma autónoma, analizando la extensión del daño en cada caso y abordando su eventual convergencia con la indemnización por incumplimiento contractual.
\end{abstract}

\section{ABSTRACT}

The present work aims to address the damages compensation as a pre-contractual remedy, systematizing the different hypotheses in which it proceeds either as complementary to invalidity or autonomously, analyzing the extent of damage in each case and their possible convergence with the compensation for breach of contract.

\section{Palabras Clave}

Indemnización de daños - Medio de tutela precontractual - Opción del acreedor.

KEYWORDS

Damages compensation - Pre-contractual remedy - Creditor's option.

\footnotetext{
* Licenciada en Ciencias Jurídicas y Sociales Universidad Adolfo Ibáñez. Doctora en Derecho Pontificia Universidad Católica de Valparaíso. Profesora de Derecho Civil de la Universidad de Valparaíso. Dirección Postal: Errázuriz 2120, Valparaíso, Chile. Correo electrónico:patriciaveronica.lopezdiaz@ gmail.com. Este trabajo forma parte del Proyecto Fondecyt de Iniciación № 11150423: "Hacia la articulación de un sistema de medios de tutela por responsabilidad precontractual en el Código Civil Chileno", del que la autora es investigadora responsable.
} 


\section{Introducción}

En la última década la doctrina nacional ha focalizado su atención principalmente en la indemnización de daños por incumplimiento ${ }^{1}$, sin que se advierta una preocupación por abordarla en sede precontractual como distinta e independiente a la nulidad, perfilarla como complementaria a ésta ${ }^{2}$, ni examinar detenidamente las posibles confluencias entre ambas indemnizaciones ${ }^{3}$. Este fenómeno probablemente encuentre explicación en el hecho que la construcción del sistema precontractual ha quedado postergado por el contractual, pues si bien se han tratado exhaustivamente las consecuencias derivadas de la ruptura de las negociaciones preliminares ${ }^{4}$, los deberes precontractuales de información, la relación que existe entre su vulneración y la validez del contrato y la violación del deber de confidencialidad ${ }^{5}$, no se ha destacado la necesidad de articularlo ni de identificar medios de tutela diversos a la nulidad que permitan conservar el contrato o fortalezcan la tutela del acreedor ${ }^{6}$.

La indemnización precontractual constituye un tópico prácticamente inexplorado ${ }^{7}$, cuya utilidad es manifiesta tratándose de negociaciones complejas, pues ellas requieren dilatados períodos que pueden acarrear cuantiosos gastos y desembolsos, reconduciéndose frecuentemente la anomalía negocial a la fase preparatoria ${ }^{8}$. A ello se agrega la necesidad de delimitarla y diferenciarla de aquella por incumplimiento, tarea que no ha resultado tan evidente para la doctrina nacional que, ocasionalmente, ha precisado que ambas pretensiones indemnizatorias son diversas en cuanto a su fundamento y alcance, ${ }^{9} \mathrm{o}$ se ha

\footnotetext{
1 Y específicamente en su procedencia autónoma o exclusiva. Una visión panorámica en LóPEZ (2015).

2 Desafío asumido en parte por RodríGuez (1995), pp. 296-303, Barros (2006), pp. 1013-1014, BaraOnA (2012), pp. 83-101 y, Pinochet y Concha (2015), pp. 129-152.

3 Excepcionalmente De La Maza (2014), pp. 132-136 y 145-146 y López (2016), pp. 679-682.

4 Domínguez y otros (1998), pp. 187-188, Barros (2006), pp. 1008-1012, De la Maza (2006), pp. 131 158, Celedón y Silberman (2010), Barrientos (2008), pp. 59-64 y 111-121, San Martín (2013), pp. 317 324, Zuloaga (2006), pp. 147-192 y Vivanco (2008), pp. 139-150.

5 Barros (2006), pp. 1014 a 1041, Segura (2007), pp. 354-355, Barrientos (2008), pp. 73-109, De la Maza (2010a), pp. 67 y ss., Ríos (2014), pp. 120-149, RodríGuez (2013), pp. 493-501, BarRientos (2015a), pp. 65-104 y BARRIENTOS (2015b), pp. 423-451.

6 No ha ocurrido lo mismo en la dogmática española. Véase Morales (2011), pp. 400-422, García (2010), pp. 1630-1642 y PANTALEón (2011), pp. 897-929.

7 Pues los autores indicados en la nota 2 sólo han abordado la indemnización complementaria a la nulidad.

8 AlONSO (1971), pp. 885-886.

9 Barros (2006), p. 1019, NúÑez (2007), pp. 338-344, Barrientos (2008), pp. 78-79; De la Maza (2010a), pp. 93-97 y OVIEDO (2014) pp. 242-267.
} 
referido sólo a aquella del artículo 1861 contemplada a propósito de los vicios redhibitorios ${ }^{10}$, sin abordar el tema con mayor amplitud ${ }^{11}$.

Claro está que la indemnización precontractual cubre el interés negativo o en la confianza, y la contractual, el positivo o en el cumplimiento, pero existe una corriente doctrinaria que postula que en aquellos casos en que el deber precontractual de información se proyecta en el contenido del contrato, el interés indemnizable es el positivo ${ }^{12}$, lo que acarrearía un doble régimen que es imperioso analizar. De otro lado, si bien el fundamento de la indemnización contractual es el contrato o su incumplimiento, según la postura a la que se adhiera, aquella precontractual procedería por infracción de determinados deberes de conducta, lo que determina la necesidad de construir un catálogo de casos y formular, si fuera procedente, una regla general que los comprenda. Piénsese en la trasmisión de información incorrecta que causa daños (porque el otro contratante generó la confianza que se celebraría el contrato o, en razón de ella, éste adoptó otras decisiones económicas), pero que no constituye un vicio del consentimiento ni un supuesto de dolo incidental. O la celebración de un contrato inválido por error o dolo, dado que de acuerdo a nuestra legislación procedería la nulidad del acto o ésta acompañada de la indemnización de daños, más no la indemnización exclusiva.

Reconocer y articular la pretensión indemnizatoria como un medio de tutela precontractual reviste particular relevancia, toda vez que permitirá al contratante que experimenta daños, cuya causa se encuentra en la fase de formación del contrato, organizar adecuadamente su estrategia de protección no sólo respecto de la nulidad, sino en el evento que tal indemnización confluya con aquella por incumplimiento. De allí que sea necesario realizar el esfuerzo dogmático que proponemos.

Para alcanzar este propósito se seguirá el esquema que referimos a continuación. En primer lugar, se sistematizarán los supuestos en que tiene lugar la indemnización precontractual, a partir del análisis de las infracciones previas y concomitantes a la celebración del contrato que causan daños al futuro contratante, con especial detención en la vulneración de los deberes de lealtad e información, subsumiendo, en el primero, el deber de confidencialidad y los vicios del consentimiento $y$, en el segundo, las declaraciones contractuales inexactas y las obligaciones de advertencia (I). Posteriormente, se identificará

10 Guzmán (2007), pp. 95-119, De la Maza (2010b), pp. 455-469, Oviedo (2014), pp. 237-274 y López (2016), pp. 659-683.

11 Excepcionalmente BARROS (2006), pp. 1008-1042.

12 Así lo han sugerido Morales (2010), pp. 89-91, De la Maza (2010 a), pp. 273-274, García y Otero (2010), p. 56 y OVIEDO (2014), pp. 251-252. 
en cuál de ellos procede la indemnización como medio de tutela autónomo o concurrente, precisando el efecto de su interposición y el alcance del interés indemnizable (II). Finalmente, se examinarán los casos en que podrían confluir la indemnización precontractual y la contractual, con el propósito de determinar si es posible advertir zonas de confluencia en las que adquiera relevancia reconocer al acreedor el derecho de optar entre ellas (III). Examinados estos tópicos, se formularán las conclusiones.

\section{Supuestos de la indemnización precontractual en el Código Civil Chileno}

Desde la obra de Rudolf von Ihering en 1861 titulada Culpa in Contrahendo bei nichtigen oder nicht zur Perfektion gelanten Verträgen, en que el autor intentó determinar si quien cometía un error esencial en la celebración de un contrato debía indemnizar el daño causado por su culpa ${ }^{13}$, la doctrina comparada ha analizado la responsabilidad precontractual o culpa in contrahendo, aglutinando en tal expresión los supuestos de nulidad del contrato por dolo, representación sin poder, vulneración de deberes precontractuales y daños personales o patrimoniales ocasionados en las fases preliminares ${ }^{14}$, sistematizando los supuestos en que resulta procedente, sin alcanzar una fórmula única y definitiva ${ }^{15}$.

La preocupación por regular la responsabilidad precontractual no se advierte en la mayoría de los Códigos Civiles; excepcionalmente la consagran, entre otros, los artículos 1337 del Codice ${ }^{16}, 227$ del portugués, 465 del boliviano, 689 del paraguayo, $\$ 311$ del $B G B^{17}, 991$ del Código Civil y Comercial argentino y, recientemente, el 1112 del Code. Ésta se ha incrementado a partir del movimiento de modernización de las obligaciones y contratos, como lo evidencian los artículos II. 3: 301 del Draft Common Frame of Refrence (DCFR), 2:301 de los Principios Europeos de Derecho de los Contratos (PECL), 2.1.15 de los Principios Unidroit sobre Contratos Comerciales (PICC) y 1245 de la Propuesta española de Modernización del Derecho de Obligaciones y Contratos $(P M E)$,

13 VON IHERING (2005), pp. 83-112.

14 Von Ihering (2005), Saleilles (1907), pp. 697-751, Faggella (1918), Benatti (1963), Alonso (1971), pp. 859- 922, Manzanares (1985), pp. 979-1009, Hondius (1991), García (1991), Caruso (1993), Cabanillas (1995), pp. 747-788, Asúa (1989), pp. 53-190, Asúa y Hualde (2003), pp. 1415-1433, VigurI (2003), pp. 79-88, Schulze (2006), pp. 29-58, Sapone (2008), Cartwright (2009), y Van Erp (2011), pp. 493-513.

15 Alonso (1971), pp. 907-914, Manzanares (1985), pp. 979-985, Asúa (1989), pp. 262-281, Cabanillas (1995), pp. 761-779, Díez-Picazo (2007), pp. 320-321, García y Otero (2010), pp. 33-53 y Pantaleón (2011), pp. 905-928.

16 Un análisis en Benatti (1963), pp. 10-16 y 19-95, Caruso (1993), Roppo, (2006), pp. 283-292 y SAPONE (2008).

17 Asúa y Hualde (2003), pp. 1419-1433 y Grundmann (2006), pp. 61-68. 
todos los cuales consagran el deber de actuar de buena fe en las negociaciones anteriores a la celebración del contrato, estableciendo la obligación de indemnizar los daños que acarree su vulneración ${ }^{18}$. Los Principios Latinoamericanos de Derecho de Contratos (PLDC), en tanto, regulan como supuestos de responsabilidad la ruptura injustificada de las negociaciones preliminares (art.11) y el incumplimiento de los deberes de confidencialidad (art. 12).

Con todo, el interés en dicha responsabilidad no se ha advertido mayormente en la civilística nacional que, ocasionalmente, ha intentado una sistematización de los supuestos de indemnización precontractual, sin contemplar todas las hipótesis posibles. En efecto, Ducci ${ }^{19}$ indica que ella tiene lugar si (i) el contrato no se lleva a efecto porque una de las partes no realiza las formalidades necesarias o no efectúa la entrega de la cosa, según el caso, y (i) habiéndose perfeccionado el contrato, una de las partes, por mala fe o negligencia, no comunicó a la otra u ocultó deliberadamente antecedentes o circunstancias o dio informaciones inexactas. Por su parte, Barros $^{20}$ señala como supuestos (i) la ruptura de las negociaciones en que una parte ha abusado de la confianza de la otra y le causa daño, (ii) la nulidad del contrato, (iii) la infracción de deberes de seguridad, información y del deber jurídico de contratar (iv) el suministro de información falsa o errónea y (v) el uso y divulgación de información privilegiada. De otro lado, Segura ${ }^{21}$ sugiere (i) la anulabilidad de un contrato válido, (ii) la ruptura de las tratativas anteriores a la oferta, (iii) el retiro de la oferta y (iv) los casos regulados por ley en que se establece una responsabilidad objetiva, como la muerte o incapacidad del oferente y la declaración unilateral de voluntad. Finalmente, Rodríguez ${ }^{22}$ distingue (i) la responsabilidad precontractual de origen convencional por incumplimiento de acuerdos preparatorios y (ii) la responsabilidad extracontractual derivada de actos precontractuales.

Sin embargo, un análisis más detenido revela que es posible simplificar el catálogo propuesto por nuestra doctrina y articular, como supuesto, la infracción de los deberes precontractuales de lealtad e información, toda vez que éstos no sólo revelan casos de contratos nulos, sino de contratos válidos, pero desventajosos para una de las partes ${ }^{23}$. Excluiremos los deberes de protección o seguridad, formulados por la doctrina alemana, que tienen por objeto evitar

18 Para un estudio comparativo véase Tomás (2010), pp. 193-207 y García y Otero (2010), pp. 5-23.

19 Duccl (1988), pp. 237-238.

20 Barros (2006), pp. 1008-1042.

21 Segura (2007), pp. 346-357.

22 Rodrícuez (2011), pp. 196-200.

23 En similar sentido García y Otero (2010), pp. 46-56 y Pantaleón (2011), pp. 905-928. 
el daño a la persona y bienes de la otra parte, derivado de las conversaciones preliminares, pues no deben concurrir en la fase anterior a la celebración de un contrato ni se vinculan necesariamente a ella. Éstos sólo se explican por la ausencia de una cláusula general que determine la procedencia de la responsabilidad extracontractual en el $B G B$, como lo ratifica el numeral 2 del $\$ 311$ que alude a una relación jurídica obligatoria preexistente ${ }^{24}$, a diferencia del Código Civil chileno que, a tal efecto, contempla el artículo 2314.

Asimismo, prescindiremos de los deberes de custodia y conservación en virtud de los cuales quien solicite mercancías u objetos para examinarlos, antes de adquirirlos, está obligado a resguardarlos y preservarlos, pues se trata de un deber general de cuidado ${ }^{25}$ que puede subsumirse en la infracción del deber de lealtad. En efecto, sólo se reconduce a una hipótesis de responsabilidad precontractual si el defecto de custodia se debe a una actuación dolosa o negligente, que defrauda el principio de confianza o, si quien solicita los objetos para examinarlos, interrumpe los tratos y aprovecha las ideas obtenidas de tal examen para confeccionar sus propios modelos ${ }^{26}$.

Como se advertirá durante las líneas que siguen, el enfoque que proponemos reporta utilidad desde tres perspectivas distintas. Y es que, además de simplificar el catálogo que ha expuesto la doctrina nacional, permite introducir la categoría genérica de los deberes precontractuales, que no ha sido mayormente abordada entre nosotros ${ }^{27}$, y contribuye a deslindar, según el caso, la indemnización precontractual de aquella contractual, admitiendo en determinados supuestos la posibilidad que el contratante opte por mantener el contrato, conformándose con una indemnización que se encuentra en una zona intermedia entre el interés negativo, propio de la primera, y el interés positivo, consustancial a la segunda.

\section{El elemento articulador: La infracción de los deberes de lealtad e información}

Sabido es que en la fase anterior a la celebración del contrato surge la denominada relación precontractua ${ }^{28}$, que comprende todos aquellos actos,

24 Alonso (1971), p. 910, Manzanares (1985), pp. 988-990, Cabanillas (1995), pp. 781 y 788, De Los Mozos (2005), p. 86, García (1991), pp. 57-58, Díez-Picazo (2007), p. 314, García y Otero (2010), pp. 26-28 y PANTALEÓN (2011), pp. 901 y 903-904. Un profundo tratamiento de esta categoría en Cabanillas (2000).

25 Principalmente Asúa (1989), p. 226. Cabanillas (1995), pp. 784 y 788.

26 Alonso (1971), p. 909.

27 Excepcionalmente han abordado este tópico, pero en términos más generales BARROS (2006), pp. 1001 y 1014-1042, Barrientos (2008), pp. 73-109 y BOetsh (2011), pp. 139-143.

28 Que para la doctrina alemana reviste un carácter obligatorio y legal AsúA y HuALDE (2003), pp. 14191433. 
situaciones o conductas que integran el iter formativo del contrato proyectado y que crean, en la otra parte, la confianza razonable que éste se celebrará29. En dicha etapa, la buena fe contractual u objetiva exige a las partes actuar con honestidad, corrección, lealtad, transparencia, coherencia y cooperación, de modo que deben guardar secreto de todo aquello que sea confidencial, proveer la información necesaria, mantener y conservar los elementos materiales que constituyen el sustrato del futuro acuerdo y no incurrir en una ruptura injustificada de los tratos preliminares ${ }^{30}$. Deviene, entonces, como una fuente creadora de especiales deberes de conducta $y$, por consiguiente, como fundamento de los denominados deberes precontractuales, cuyo propósito es preparar adecuadamente el cumplimiento de la prestación. Tales son los deberes de lealtad, información, confidencialidad o secreto, conservación y custodia ${ }^{31}$.

Una realidad distinta se advierte en el Common Law, pues, desde antiguo, se ha sostenido que no existe un deber general de comportarse de buena fe ni deberes precontractuales de información, atendida la reluctancia a recurrir a principios generales, la dificultad de definir un deber y la relación adversarial que existe entre las partes durante las negociaciones ${ }^{32}$. Con todo, en las últimas décadas se han reconocido, tratándose de las garantías contractuales, la misrepresentation, los ilícitos civiles, contratos especiales que requieren revelar información, las relaciones fiduciarias, la costumbre y la ley ${ }^{33}$ y se ha propuesto prohibir una actuación de mala fe, en vez de exigir una conducta que se ajuste a la buena fe, con el propósito de arribar a una solución intermedia que permita armonizar el derecho privado europeo ${ }^{34}$.

Lo cierto es que, al igual que la responsabilidad precontractual, tales deberes no han sido objeto de una regulación específica en la mayoría de los códigos civiles decimonónicos, admitiéndose su existencia a partir de la función integradora de la buena fe contractual, toda vez que impone a las partes que tratan o negocian, un arquetipo de conducta que se traduce en la observancia de

29 Betti (1969), pp. 91-92. Larenz (1958), pp. 154-156. Alonso (1971), pp. 862-865, 879 y 887. Manzanares (1984), p. 708. Asúa (1989), pp. 55- 62 y Medina (2005), pp. 104-105.

30 Entre otros, Larenz (1958), pp. 21-22. Díez-Picazo (1964), p. 363. Benatti (1963), pp. 35 y ss., especialmente pp. 99-113. BetTI (1969), pp. 72-73 y 104-105. CABANILlas (1995), pp. 750 y 753. Storme (2003), p. 21. Lorenzetti (2004), pp. 304-305. Monsalve (2008), pp. 32-40 y Borda (2014), pp. $43-44$ y 49 .

31 Sin embargo, García subsume todos estos deberes en el de lealtad, García (1991), pp. 44-55.

32 Giliker (2006), pp. 303-306 y 319. Cartwright (2007), pp. 65-70. Banakas (2009), pp. 4-8. Hesselink, (2011), p. 620. VAN ERp (2011), pp. 494-495, 500-505 y 508 y Beale y otros (2010), pp. 372-376.

33 Una visión panorámica en GILIKER (2006), pp. 306-319.

34 Van Erp (2011), p. 513 y Beale (2012), pp. 98-99. 
aquellos. Dicha función puede extraerse del artículo 1546 de nuestro Código, en la parte que prescribe que la buena fe obliga a "todas las cosas que emanan precisamente de la naturaleza de la obligación, o que por ley o costumbre pertenecen a ella", dado que, la expresión "cosas", envuelve la idea que, a partir de cada obligación puede derivarse algo no declarado, pero necesario para la total satisfacción de la prestación obligacional. Por lo mismo, exige un examen de la obligación y de su naturaleza, para determinar si de ella emana otra "cosa" que deba ser considerada obligatoria, aunque así no se haya expresado ${ }^{35}$.

Si bien tal razonamiento ha sido recogido por nuestros tribunales ${ }^{36}$ e incluso se ha sustentado su construcción en normas generales y particulares contenidas en el Código Civil ${ }^{37}$, la dogmática nacional ha centrado su atención en el deber precontractual de información ${ }^{38}$, pero no ha abordado con detención la configuración del deber de lealtad ni las consecuencias derivadas de su infracción ${ }^{39}$, lo que impide al contratante constatar que, al igual que en el supuesto de infracción del deber de información, puede demandar la indemnización precontractual. Con todo, como se apreciará en las líneas que siguen, es posible advertir en nuestro Código Civil la existencia de ambos deberes precontractuales, cuya infracción deviene precisamente en el elemento articulador de dicha indemnización.

\section{a. Infracción del deber de lealtad}

El deber de lealtad es aquel que impone a quienes negocian un contrato una conducta correcta y honesta, que se traduce en no iniciar ni continuar negociaciones sin la intención real de llegar a acuerdo, o en conocimiento que el contrato que va a celebrarse no es válido, guardar el debido secreto de la información obtenida durante ese período, no dar a conocer la existencia de negociaciones paralelas y respetar los pactos de exclusividad existentes ${ }^{40}$.Y es que, como ya señalaba De Cossío ${ }^{41}$ en 1975, "el hecho de ponerse en contacto dos personas a fin de negociar la conclusión de un contrato establece, entre

35 GuZMÁN (2002), p. 17.

36 Sobre esta tendencia BoEtsh (2011), p. 117, notas 191 y 192 y CORRAL (2010), pp. 79-83.

37 PRADO (2015a), pp. 30-36.

38 Barros (2006), pp. 1014-1027. De la Maza (2011) y Barrientos (2015a) y (2015b).

39 A excepción de Barros (2006), pp. 1014-1042. Barrientos (2008), pp. 73-109 y BoetSh (2011), pp. 139-143.

40 En tal sentido Arroyo (2003), p. 338. García (1991), pp. 53-54 y Pantaleón (2011), p. 906. En la doctrina chilena, Barros (2006), pp. 1001 y 1008-1012 y BOETSH (2011), p. 140.

41 De Cossío (1975), p. 264. 
ellas, una cierta conexión y crea un estado de recíproca confianza, que no debe ser defraudado, pues, una y otra, se deben un mínimo de lealtad en el trato".

Si bien dicho deber no se encuentra expresamente regulado en nuestro Código Civil, su existencia no sólo se desprende del artículo 1546, relativo a la buena fe contractual, sino también de los artículos 1451 a 1459 que regulan los vicios del consentimiento, el artículo 1814 referente a la falta de objeto, los artículos 1685 y el 1688 a propósito del dolo del incapaz y la contratación con éste sin las formalidades legales, y los artículos $2154 \mathrm{~N}^{\circ} 1$ y 2173 relativos a la falta de poder de representación. A partir de tales normas, es posible sostener que el deber de lealtad se infringe en las siguientes hipótesis que conllevan, en su mayoría, la indemnización de daños en el interés negativo. Tales son: (i) la ruptura injustificada de las tratativas preliminares, (ii) la celebración de un contrato inválido y (iii) la infracción del deber de confidencialidad.

\section{i. Ruptura injustificada de las tratativas o negociaciones preliminares}

Formulado en sus inicios por Faggella en $1906^{42}$, este primer supuesto es el que ha concitado mayormente la atención de la dogmática comparada y nacional ${ }^{43} \mathrm{e}$ incluso ha sido regulado en forma expresa en los artículos 1337 y 1338 del Codice y 227 del Código Civil portugués y, en las últimas décadas, en los artículos 2:301 de los PECL, 2.1.15 de los PICC, II-3:301 del DCFR, 1245 de la $P M E$ y 11 de los $P L D C$, reconociéndose, en todos ellos, la libertad para iniciar y romper las negociaciones, en la medida que tal actuación se ajuste a la buena fe y no cause daños a la contraparte.

Y es que existe consenso en que la justificación de la indemnización, en este caso, se encuentra en el hecho que las negociaciones han alcanzado un estado tal que han creado objetivamente en la otra parte la legítima confianza que el contrato se perfeccionará, dado que sólo falta su celebración o la discusión de cuestiones menores. Es precisamente tal circunstancia la que determina que aquella incurra en gastos para concluirlo o renuncie a otras ofertas, de modo que una ruptura incausada frustrará sus expectativas y le generará daños que deben resarcirse ${ }^{44}$. Por consiguiente, la responsabilidad no surge como conse-

\footnotetext{
42 Y ampliado por el autor en una segunda edición. Véase FagGella (1918).

43 Alonso (1971), p. 912. Manzanares (1984), pp. 687-748. Asúa (1989), pp. 152-164 y 276-278. Cabanillas (1995), pp. 762-766. Arrovo (2003), pp. 336-341. Medina (2005), pp. 80-105. De Los Mozos (2005), pp. 77-99. García y Otero (2010), pp. 33-43. Quesada (2011), pp. 55-107. Pantaleón (2011), pp. 906-911 y BERNAD (2015), pp. 11-50. En la doctrina nacional véanse los autores indicados en la nota 4.

44 La ruptura sería justificada si las condiciones de mercado han variado y el negocio ya no es conveniente, surge una oferta más beneficiosa, no es posible llegar a acuerdo sobre un aspecto del contrato o se produce la pérdida no culpable de un derecho necesario para su celebración (BARROS (2006), p. 1011 y De LA MAZA (2006), p. 150. Díez-Picazo agrega la enfermedad sobrevenida, que
} 
cuencia de la ruptura, sino de la defraudación de la confianza generada por la otra parte, independientemente si desde un principio ha tenido la intención de no contratar (e impedir que la contraparte se vincule con un tercero para obtener una ventaja competitiva) o ésta ha surgido después de iniciadas las conversaciones, desatendiéndose gravemente el interés de la otra parte ${ }^{45}$.

La responsabilidad precontractual por ruptura injustificada de las negociaciones preliminares no pretende, entonces, exigir que quienes inician conversaciones preliminares, elaboran proyectos, borradores o minutas, negocian objetivos y ponderan posibilidades, resulten obligados a celebrar un contrato, sino alcanzar el debido equilibrio entre la libertad contractual, que no puede ejercerse de forma abusiva, y la buena fe objetiva, que impide el retiro arbitrario de quien ha generado la confianza razonable en torno a la conclusión del contrato proyectado. Piénsese, por ejemplo, en el caso que una de las partes asegure a la otra que el contrato se celebrará en una fecha diversa o la induce a anticipar su prestación, efectuando sustantivas mejoras al inmueble que pretende arrendar $^{46}$. Otro tanto acontecerá si un individuo entra en negociaciones con otro para obstaculizar la celebración de un contrato entre este último y un tercero y, después de lograr su propósito, rompe las negociaciones con aquél y, aprovechándose de su situación de vulnerabilidad, celebra el contrato en condiciones mucho más ventajosas ${ }^{47}$.

De allí que deba indemnizarse el interés negativo, dejando al perjudicado en la situación en que se habría encontrado si las negociaciones no se hubieran iniciado o no hubiere llegado a confiar en la celebración del contrato ${ }^{48}$, comprendiendo los gastos e inversiones inútilmente realizadas (daño emergente), encontrándose limitada por aquella propia del interés positivo o en el cumplimiento ${ }^{49}$. Y es que no parece razonable que el perjudicado quede en una mejor situación que aquella en que se encontraría si el contrato se hubiera celebrado y cumplido ${ }^{50}$. Así, si el demandado prueba que la ruptura injustificada favoreció al

impide desarrollar la actividad comercial proyectada, y el rechazo de la modificación de una cláusula ambiguamente redactada. Dízz-Picazo (2007), p. 323.

45 En tal sentido Barros (2006), pp. 1010-1012.

46 Manzanares (1984), p. 715. Barros (2006), p. 1011 y Pantaleón (2011), p. 907.

47 Este supuesto es analizado por GarCía (2012), pp. 265-269.

$48 \mathrm{Y}$ es que exigir la indemnización del interés positivo equivaldría a sostener que la lealtad en las negociaciones le impondría el deber de no romperlas, compeliéndolo a contratar. PANTALEÓN (2011), pp. 907-908.

49 Así también lo ha admitido nuestra Corte Suprema. San Martín (2013), pp. 317-323.

50 Pantaleón (2011), pp. 908-909 y San Martín (2013), p. 323. En la doctrina nacional, en tanto, Rosende admite este límite para la indemnización derivada de la revocación de la oferta. RosenDE (1979), p. 99. 
demandante, pues lo liberó de pérdidas que la celebración del contrato habría acarreado, aun cuando aquél hubiera actuado dolosamente, no procedería tal indemnización ${ }^{51}$. Con todo, se ha sostenido que si la ruptura injustificada de las tratativas preliminares tiene por propósito privar al otro negociante del beneficio cierto que la celebración del contrato le podía reportar, la indemnización comprenderá el interés positivo o en el cumplimiento ${ }^{52}$.

Se ha discutido, sin embargo, si debe resarcirse la pérdida de la oportunidad de celebrar un contrato equivalente o más ventajoso (lucro cesante) $)^{53}$. Con todo, quienes abogan por ella admiten la dificultad de establecer qué tipo de oportunidades serán estas alternativas y si en realidad no se estaría reconociendo una reparación integral o por el interés positivo, aunque sea por vía oblicua ${ }^{54}$. Lo cierto es que, más que dar cabida a la indemnización del interés positivo -lo que resulta discutible si se piensa que efectivamente se perdió una oportunidad de negocio que se habría tenido de no haber entrado en las negociaciones-, el daño es indemnizable en sede precontractual si existe una relación de causalidad entre éste y la confianza suscitada por la contraparte en la conclusión del contrato ${ }^{55}$.

Tal relación no se advierte en la pérdida de la oportunidad de un negocio más ventajoso, toda vez que la confianza del contratante defraudado se predica respecto del negocio que proyectó celebrar con quien se retira de la negociación, y no del que podría haber celebrado con un tercero, ya que ni siquiera existe certeza que éste fuera a concluirse. Es precisamente la ausencia de esta relación de causalidad la que explica que se excluyan los gastos de publicidad, o aqueIlos que derivan de estudios de planes y proyectos preliminares de la oferta o propuesta recibida, pues los primeros son de cargo de la persona que propone el contrato y que se beneficia de ellos, en tanto, los segundos, encuentran su causa en una actividad comercial que lleva implícita un riesgo. Siguiendo el mismo razonamiento, resulta lógico excluir los gastos que se realizan sin el asentimiento de la persona con la que se va a contratar ${ }^{56}$.

51 PANTAleón (2011), p. 909.

52 Morales (2014), p. 231.

53 A favor de ella Medina (2005) p. 89, Barros (2006), pp. 1007-1008. De la Maza (2006), pp. 156-157. García y Otero (2010), pp. 34-35, 41 y 43 y Pantaleón (2011), p. 907. En contra, Manzanares (1984), pp. 747-748. e inicialmente Dírz-Pıcazo (2002), p. 199, pues posteriormente la admite Dírz- Picazo (2009), p. 190. Por su parte, Rosende descarta la indemnización del lucro cesante, pero la reconoce por revocación de la oferta, distinguiendo si existe convención sobre gastos y accidentes, ROSENDE (1979), pp. 79 y 99.

54 García (2010), p. 1631.

55 De la Maza (2006), p. 156 y Díez-Picazo (2007), pp. 323-324.

56 Hilserand (1932), p. 16. Rosende (1979), p. 52 y Manzanares (1984), pp. 741-743. 
Un fenómeno similar al consignado a propósito de la ruptura injustificada de las tratativas preliminares, se produce en fases más avanzadas de las negociaciones precontractuales, como acontece si el oferente revoca su oferta y el destinatario la ha aceptado, la aceptación es extemporánea y el oferente no comunica esta circunstancia al destinatario de la oferta, falta el cumplimiento de una solemnidad o la entrega de la cosa para que el contrato se perfeccione e, incluso, en aquellos casos en que el destinatario de la oferta ha generado la legítima confianza en que celebrará el contrato, no obstante lo cual se arrepiente $^{57}$. En todos estos supuestos pueden causarse daños al otro contratante que deberán indemnizarse, situándolo en el estado en que se encontraría de no haber avanzado en la negociación del contrato.

Claro está que nuestro Código Civil no regula la formación del consentimiento, pues tales reglas están contenidas en los artículos 98 a 100 del Código de Comercio, que prevén expresamente las hipótesis a las que nos hemos venido refiriendo. Así, el artículo 98 señala que en caso de aceptación extemporánea, el oferente será obligado a dar pronto aviso de su retractación, pues de lo contario será responsable de los daños que la falta de éste ocasione y el artículo 100 prescribe que, en caso de retractación tempestiva, el proponente deberá indemnizar los gastos en que el destinatario hubiere incurrido y los daños que se le hubieren ocasionado.

Sin embargo, ellos sirven para dotar de contenido a esta dimensión del deber de lealtad que debe imperar durante las negociaciones preliminares y configurar el ilícito civil que hace procedente la aplicación del artículo 2314 del Código Civil, más allá de los presupuestos de aceptación extemporánea y retractación intempestiva previstos en el Código de Comercio. De allí que algunos autores nacionales postulen que el fundamento de la indemnización por ruptura injustificada de las tratativas preliminares se encuentra en el abuso del derecho, la doctrina de los actos propios, la contravención al principio de buena fe o la infracción del deber de cuidado que deben observar las partes en la etapa precontractual, encuadrándolo en la responsabilidad civil extracontractual ${ }^{58}$.

Rodríguez, en tanto, disiente de este planteamiento, indicando que no se trataría de supuestos de responsabilidad precontractual, sino legal, toda vez que encontrarían su fundamento en el Código de Comercio ${ }^{59}$. Con todo, esta crítica

\footnotetext{
57 De hecho, opiniones autorizadas tratan estas hipótesis junto a la ruptura de las tratativas preliminares 'véanse Cossío (1955), pp. 299-301, Díez-Picazo (2007), pp. 318 y 320. Asúa (1989), p. 158, Barros (2006), pp. 1008-1012. Un acabado análisis de estos supuestos en el derecho chileno, en Rosende (1979), pp. 79-88 y 97-112.

58 Para una visión panorámica véase Celedón y Silberman (2010), pp. 118-132.

59 Rodríguez (2011), p. 198.
} 
se diluye si se considera que la doctrina y jurisprudencia mayoritarias se han inclinado por atribuirle naturaleza extracontractual a la responsabilidad legal, de modo tal que el recurso a las normas del Título 35 del Código Civil resulta insoslayable. De hecho, nuestro máximo tribunal ha justificado la procedencia de tal indemnización en el artículo 2314, de modo que puede sostenerse que, implícitamente, ha admitido la existencia del deber de lealtad precontractual en nuestro Código Civil y la indemnización como consecuencia derivada de su infracción ${ }^{60}$, deviniendo, indiscutidamente, en autónoma o exclusiva, toda vez que, a diferencia de otros supuestos que examinaremos en este artículo, no acompaña a la nulidad.

\section{ii. Celebración de un contrato inválido}

El segundo supuesto de responsabilidad precontractual fue precisamente el que formuló lhering ${ }^{61}$ en 1861, inicialmente circunscrito al error esencial y extendido con posterioridad a los que denominó (i) casos en que un contratante es inducido a celebrar el contrato por dolo o fraude (incapacidad de las partes), (ii) supuestos en que éste se celebra sabiendo que la prestación es imposible o ilícita (inidoneidad del objeto) y (iii) hipótesis en que se omite comunicar el desistimiento del contrato, se efectúan declaraciones poco claras, erróneas o simuladas o se emprende una actividad aparente (inexactitud de la voluntad contractual).

Este caso de infracción del deber de lealtad ha adquirido importancia no sólo en el Codice, cuyo artículo 1338 impone la obligación de indemnizar a quien conociendo o debiendo conocer la existencia de una causa de invalidez del contrato no la ha comunicado a la otra, sino también en los códigos más modernos, como lo revelan el $\$ 122$ del BGB, los artículos 465, 690 y 991 de los códigos civiles de Bolivia y Paraguay y del Código Civil y Comercial argentinos, respectivamente, y los artículos 15:105 de los PECL y Il.- 7:304 del DCFR. En efecto, ellos consagran, en términos generales, la siguiente regla: la parte de un contrato que resulta ineficaz, podrá exigir a la otra una indemnización que la deje en la situación más semejante a la que habría tenido si el contrato no se hubiera celebrado, siempre que la otra parte conociera o debiera haber conocido la causa de la ineficacia. El $\$ 122$ del $B G B$ incluso precisa que tal indemnización no debe exceder la cuantía que el otro contratante tenía en la validez de la declaración. No ocurre lo mismo en los PLDC, pues su versión definitiva no contiene una norma similar.

60 Por todos Barros (2006), pp. 1003 y ss. Domínguez y otros (1998) y Domínguez (2005), pp. 305-311.

61 Un análisis de tales supuestos en Von IHERING (2005), pp. 83-112. 
Y es que resulta de toda lógica que la acción de nulidad y la indemnización de daños sean compatibles, dado que persiguen propósitos distintos, de modo que advertiremos casos en que la pretensión indemnizatoria deviene como complementaria y otros en que puede intentarse en forma exclusiva. Con todo, ninguno de tales preceptos precisa cuáles serían las hipótesis en que la celebración de un contrato nulo daría lugar a la indemnización precontractual, por lo que se hace necesario sistematizarlos a partir de las normas contenidas en nuestro Código Civil e intentar extraer una regla general. Para alcanzar tal propósito examinaremos los vicios del consentimiento, la incapacidad de uno de los contratantes, la falta de objeto y causa, el objeto y causa ilícitos, la actuación del falso procurador cuyo poder no ha sido ratificado, y las hipótesis en que el perjudicado renuncia al ejercicio de la acción de nulidad o ésta ha prescrito.

Excluiremos la inobservancia de las formalidades ad solemnitatem y habilitantes, dado que su cumplimiento es un deber de ambos contratantes, de modo que su omisión da lugar a una compensación de culpas que excluye la indemnización ${ }^{62}$. También prescindiremos de la lesión enorme, toda vez que ella no acarrea, en ninguno de los casos que el legislador la contempla, la nulidad relativa del acto o contrato, sino la rescisión, no pudiendo subsumirse en este segundo supuesto articulador de la indemnización precontractual.

\section{- Indemnización de daños por vicios del consentimiento}

Sabido es que los vicios del consentimiento facultan para demandar la nulidad relativa del acto o contrato celebrado. Sin embargo, ello no impide al perjudicado solicitar, además, los daños que la declaración de dicha nulidad acarree, pues se trata de acciones distintas e independientes, toda vez que sus fundamentos y consecuencias son diversos. En efecto, la acción de nulidad supone un vicio y persigue aniquilar el acto o contrato celebrado; la acción indemnizatoria, en cambio, exige daño y pretende resarcir al perjudicado. $\mathrm{Ni}$ siquiera podría discutirse si esta última se encuentra sujeta al plazo de prescripción previsto para la responsabilidad contractual en el artículo 2515, o para la extracontractual, en el artículo 2332, ya que se trata de un tema zanjado en la doctrina y jurisprudencia nacionales, dado que, como ya hemos precisado, a la responsabilidad precontractual se aplican las normas de la extracontractual ${ }^{63}$.

En efecto, si existió dolo para obtener el consentimiento, resulta procedente la indemnización por los daños ocasionados a la contraparte, toda vez que éste no sólo constituye un vicio del consentimiento, sino una causa de responsabilidad

62 Rodríguez (1995), pp. 287 y 294. Y es que la ley se presume conocida por todos, de modo que no es posible reclamar falta de conocimiento para obtener una indemnización BARAONA (2012), p. 97.

63 Por todos Barros (2006), pp. 1003 y ss. Domínguez y otros (1998) y Domínguez (2005), pp. 305-311. 
derivada de una conducta reprochable ${ }^{64}$, deviniendo en un criterio de imputación que adquiere especial importancia en la etapa precontractual. De allí que pueda sostenerse que, sea que exista dolo causante o incidental, procede la indemnización de daños, de modo que no se trata de un efecto privativo de este último, a pesar que el inciso segundo del artículo 1458 del Código Civil lo prevea exclusivamente en dicho supuesto ${ }^{65}$. Más aún si tal distinción ha sido calificada de artificiosa y suprimida en algunos códigos civiles como el $B G B$ y omitida en los instrumentos de modernización del derecho contractual ${ }^{66}$. Cuestión diversa es que, en caso del dolo incidental, se infrinja un deber de información que origine la obligación de indemnizar, pues, como precisaremos al analizar tal deber, ésta es de naturaleza contractual.

Un fenómeno similar se advierte tratándose de la fuerza que vicia el consentimiento, pues como ella debe ser ilícita, si causa daño, éste deberá repararse de conformidad a las normas del Título 35 del Libro IV de dicho Código. En el evento que la fuerza provenga de un tercero, la víctima podrá impetrar la nulidad, como lo admite expresamente el artículo 1457, pero si el otro contratante actúa junto al tercero o colabora con él, también deberá indemnizarla. El problema se presenta si dicho contratante estaba de buena fe, es decir, desconocía excusablemente la actuación del tercero y confió en que su contraparte manifestó libremente su voluntad, pues si esta última impetra la nulidad y reclama la indemnización al tercero, la aniquilación del contrato puede perjudicarlo. En tal caso, estimamos que dicho contratante de buena fe podría reclamar la indemnización al tercero, toda vez que la causa del daño que experimenta se encuentra precisamente en la violencia que aquél ejerció en la víctima ${ }^{67}$.

Distinto es el caso del error, pues su existencia no determina un ilícito per se. Y es que podría pensarse que resulta indiscutido que el error daría lugar a una indemnización precontractual, sea que lo padezca el declarante o el destinatario de la declaración, en la medida que la impugnación del contrato cause daños a la otra parte. Sin embargo, para que ello ocurra se requiere que tal error sea

\footnotetext{
64 Morales (1982), pp. 595 y 597. Por su parte, Rojo indica que, si el dolo vicio ha causado daño, la víctima tiene dos acciones que podrá ejercer conjunta o independientemente (Rojo (1994), p. 124), distinguiendo el dolo norma de validez y norma de responsabilidad (Rojo, pp. 118-147). En dirección más general Cossío (1955), pp. 363-365.

65 BARAONA (2012), pp. 90-91, precisando que la expresión "solamente" del inciso segundo del artículo 1458 es indicativa que la indemnización está disponible para los casos del inciso primero, esto es, para el dolo vicio. Una reflexión similar a propósito del artículo 1270 del Código Civil español en MORALES (1982), p. 603.

66 Morales (1982), pp. 602-603 y García (1991), pp. 166 y 167. Sobre la falta de claridad entre ambas clases de dolo véanse Morales (1982), pp. 603-604 y Rojo (1994), pp. 153-179.

67 García (1991), pp. 185-187. En la doctrina nacional Rodríguez (1995), p. 289, y BaraOna (2012), p. 92.
} 
excusable, esto es, no imputable a la culpa o negligencia de quien lo padece -a menos que el perjudicado conociera o debiera haber conocido la causa de la nulidad-, dado que sólo en ese caso éste podría viciar el consentimiento y la víctima de tal error solicitar la nulidad del contrato, de la que derivará el daño para quien ha contratado con ella, quedando obligada a resarcírselo ${ }^{68}$.

Claro está que el Código Civil no contempla la excusabilidad del error para que éste vicie el consentimiento, discutiéndose si, a partir de sus disposiciones, ésta puede deducirse como requisito. Así, por un lado, se ha justificado su procedencia en el aforismo nemo auditor propiam turpitudinem allegans consagrado en el artículo 1683 y en regla contenida en el inciso tercero del artículo 706 , según la cual un justo error no se opone a la buena $f e^{69} ; y$, por otro, se ha descartado, a falta de precepto legal que consagre tal exigencia ${ }^{70}$. Adherir a esta última postura amplía las hipótesis en que puede demandarse la nulidad, y la consiguiente indemnización, en tanto, plegarse a la primera, las restringe. Con todo, nos inclinamos por la excusabilidad del error como requisito para que éste vicie el consentimiento, toda vez que así se desprende de una interpretación armónica de las normas antes referidas y de la constatación que el error es un dispositivo de distribución de riesgos de la información defectuosa que no protege al que se comporta negligentemente, sino al destinatario de la declaración ${ }^{71}$.

Pero, más allá de esta controversia, el problema se ha presentado respecto del error esencial, el error sustancial y el error accidental que nuestro Código regula, respectivamente, en los artículos 1453, 1454 inciso primero y 1454 inciso segundo, debatiéndose si, efectivamente, éstos permiten demandar indemnización. Así, Rodríguez ${ }^{72}$ ha sostenido que en los dos primeros casos ella nunca procede, pues ambos contratantes sufren equivocación, de modo que las culpas se compensan como consecuencia de la aplicación del artículo 2330, fenómeno que también se advierte en el tercer tipo de error, si habiendo errado uno de los contratantes en la calidad accidental de la cosa, el otro cree que ella está presente y persiste en el contrato, conociendo cuál es el motivo que induce

\footnotetext{
68 Asúa (1989), pp. 265-268. García (1991), pp. 159-164. Sin embargo, De Cossío (1955), pp. 365-369 y Morales (2004), p. 381, han negado la indemnización en supuestos de error, restringiéndola a los casos de dolo.

${ }^{69}$ Claro Solar (1979), p. 154. León (1990), p. 130. Martinic y Reveco (2005), pp. 269-270, De La Maza (2012a), pp. 516-518. Domínguez (2012), pp. 80-82.

70 BaraOna (2012), p. 93.

71 Abogando por tal enfoque Morales (1988), pp. 88-90. De la Maza (2012a), pp. 515-531.

72 Rodríguez (1995), pp. 289 y 290. El autor precisa que si el contratante hubiera tenido conocimiento que faltaba la calidad accidental y persistiera en contratar, estaríamos ante un contratante doloso.
} 
a contratar. Baraona ${ }^{73}$, en tanto, ha señalado que tratándose del error esencial y sustancial no necesariamente ambas partes incurrirán en él, porque sólo una de ellas confundiría la realidad, caso en el cual, la otra podrá, en la medida que haya ignorado el error de la primera, demandar la indemnización del daño derivado de la nulidad, aduciendo que no es justo que sufra la privación de la expectativa contratada si ella no ha provocado tal error.

Distinto es el caso del error en la persona, toda vez que el artículo 1455 del Código Civil prevé expresamente la procedencia de la indemnización derivada de la nulidad por tal error, otorgándole el derecho a demandarla a aquella persona con la que erradamente se contrató, si estaba de buena fe. A nuestro juicio, esta norma ratifica la procedencia general de la indemnización por error, toda vez que no se advierte el motivo por el cual el legislador consagró la pretensión indemnizatoria por nulidad tratándose del error en la persona y no a propósito de los otros tipos de error, si en todos estos supuestos la nulidad puede ocasionar daños al otro contratante. Una explicación razonable, a nuestro juicio, sería entender que el legislador formuló en tal precepto una regla que no se constriñe al error en la persona, sino que reviste un carácter general, que puede construirse a partir del aforismo ubi edem ratio ibi ius ${ }^{74}$ y que su fundamento se encuentra, precisamente, en el daño ocasionado por la nulidad y no, como lo ha sostenido un sector de nuestra doctrina, en la regla de las prestaciones mutuas contenida en el artículo 1687 del Código Civil ${ }^{75}$.

Sin embargo, en el último tiempo, el movimiento de modernización del derecho de obligaciones y contratos, ha sugerido concebir al error como un dispositivo de distribución del riesgo de la información defectuosa durante la negociación del contrato más que como un vicio del consentimiento, pues, de lo contrario, quien lo padece traspasa el riesgo al otro contratante, que ha confiado razonablemente en la apariencia creada por aquél. De allí que este enfoque proponga que el errans deba soportarlo, protegiendo dicha confianza, a través de la mantención del contrato ${ }^{76}$. Con todo, en el evento que en el futu-

73 BaraOna (2012), p. 92-94.

74 Por una aplicación analógica del artículo 1455 del Código Civil a otros errores excusables León (1991), p. 142. MARTINIC y ReVECO (2005), p. 294.

75 Martinic y ReveCo (2005), pp. 294-295. No concordamos con esta postura, pues se ha causado un daño que debe resarcirse y que no queda absorbido por el efecto restitutorio de tales prestaciones, dado que la acción restitutoria es una consecuencia de la nulidad y no reviste naturaleza indemnizatoria (Rojo (1994), p. 127-128). Tampoco con la idea que los deterioros tienen naturaleza indemnizatoria (PinOCHET y CONCHA (2010), pp. 147, 149 y 150), dado que al constituir una prestación mutua, ellos quedan subsumidos en el efecto restitutorio.

76 Esta idea planteada inicialmente por Morales (1988), pp. 88-90. fue recogida en los artículos 3.2.2 de los PICC, 4:103 de los PECL, II.- 7:201 del DCFR, 1298 de la PME y 29 de los PLDC. Destacando 
ro se acogiera tal interpretación por nuestra jurisprudencia, igualmente podría tener cabida la pretensión indemnizatoria, pues como ya hemos indicado, es distinta e independiente de la nulidad, con la salvedad que, en tal supuesto, ya no nos encontraríamos ante un contrato ineficaz, sino ante uno válido en que además procedería dicha pretensión, como veremos en el apartado siguiente.

Lo que resulta indiscutido es que, atendido que la indemnización encuentra su fundamento en un daño provocado por un vicio del consentimiento y éste ha tenido lugar en la fase precontractual, la indemnización comprenderá el interés negativo, esto es, dejará al perjudicado en la situación en que se encontraría de no haber celebrado el contrato, siempre que la otra parte hubiera sabido o debido saber la existencia del vicio del consentimiento ${ }^{77}$. Y es que ahí donde no alcanzan las reglas de la nulidad, adquieren utilidad aquellas propias de la pretensión indemnizatoria, pues permiten resarcir el daño emergente, representado por las pérdidas positivas o gastos inútiles y el lucro cesante por ganancias frustradas o dejadas de obtener ${ }^{78}$.

\section{- Indemnización derivada de la celebración de un contrato con un incapaz}

En este segundo supuesto de indemnización, al igual que en el caso del error, y a diferencia del dolo y fuerza en que la antijuridicidad de la actuación es evidente, la ilicitud de la conducta no se configura por la existencia de la incapacidad, sino por el hecho que la nulidad derivada de la contratación con un incapaz causa daños al otro contratante, lo que supone determinar cuándo resulta procedente, y diferenciar los casos en que la solicita el incapaz o el otro contratante.

Claro está que los casos a examinar se restringen a la celebración de un contrato con uno de los incapaces relativos a que se refiere el artículo 1447 del Código Civil, esto es, un menor adulto o un pródigo declarado en interdicción de administrar lo suyo, toda vez que el daño causado debe ser imputable y, como los incapaces absolutos no tienen voluntad, no podrían actuar dolosa o culposamente. De allí que se limite la aplicación del artículo 1685 a los incapaces relativos. Con todo, es posible que la persona capaz intente aprovecharse del absolutamente incapaz contratando con él y no con su representante legal,

este planteamiento en la doctrina nacional DE LA MAZA (2012a), pp. 511-523 y a propósito del Borrador de los PLDC, De La Maza (2015), pp. 789-799.

77 Así lo admiten expresamente los artículos 4:117 de los PECL y II.7:214 del DCFR.

78 Morales (2003), pp. 394-396 y JeRez (2011), pp. 293, 295 y 297. Con todo, algunos autores nacionales han descartado que la nulidad conlleve la indemnización del lucro cesante, indicando que sería contradictorio sostener que el acto es nulo y otorgar a una de las partes el beneficio proyectado como si el acto hubiera sido válidamente convenido (RodríGuez (1995), p. 297. GuZMÁn (2007), pp. 110-111). 
omitiendo la formalidad habilitante que exige la ley, caso en el cual éste podrá solicitar a través de su representante la nulidad del acto, invocando el artículo 1688 del Código Civil y la consiguiente indemnización de los daños que ella le acarree.

Sin embargo, Rodríguez ${ }^{79}$ ha postulado que los actos nulos celebrados por incapaces relativos no dan lugar a la indemnización de daños en atención a dos consideraciones. En primer lugar, indica que quienes inducen al incapaz a contratar, conociendo de su incapacidad, se exponen a la sanción del artículo 1688 que elimina todo perjuicio al permitir al incapaz retener lo dado o pagado en virtud del contrato, a menos que se hiciera más rico, quedando así cualquier daño subsumido en tal disposición. Por otra parte, señala que no podría otorgarse indemnización a quien contrata con el incapaz, pues se tornaría ilusoria la protección que la ley le dispensa. Ello explica que el artículo 1685 sancione el dolo del incapaz privándolo de la posibilidad de alegar la nulidad del contrato, erradicando así la indemnización de los daños derivados de ella en favor del otro contratante.

Disentimos de esta opinión, pues estimamos que un análisis más casuístico permite advertir algunas hipótesis en que la indemnización es procedente. En efecto, si una persona capaz celebra un contrato con un incapaz, puede encontrase en algunas de las siguientes hipótesis: (i) el incapaz lo ha engañado, induciéndolo a creer que es capaz, (ii) el contratante no se percata de tal incapacidad por su propia negligencia, (iii) advirtiéndola, omite las formalidades habilitantes exigidas por ley o (iv) induce maliciosamente al incapaz a celebrar el contrato para aprovecharse de él. Los dos primeros supuestos están previstos en el artículo 1685 que consagra el principio de malitia supplet aetatem, pero de diferente forma: el primero explícitamente y el segundo implícitamente. El tercer supuesto está regulado en el artículo 1688 a propósito de los efectos de la nulidad como una excepción al efecto restitutorio de aquella y el cuarto, si bien no está contemplado específicamente, puede subsumirse en la regla prevista en los artículos 2314 y 2319 del Código Civil.

En efecto, la primera parte del artículo 1685, impide al incapaz que ha inducido dolosamente a celebrar el acto o contrato, a sus cesionarios o herederos, demandar la nulidad, protegiendo la confianza del contratante de buena fe, de modo tal que no existirán daños derivados de aquella, pues el contrato sigue vigente. Pero nada obsta a que el otro contratante inste por la nulidad, invocando precisamente el dolo del incapaz -que, por lo mismo, privará a este último de los daños derivados de aquella- y por la indemnización de los daños

79 RodríGuez (1995), p. 291. 
que ella le ocasione ${ }^{80}$. En tanto, la segunda parte de dicho precepto, al precisar que la aserción de mayor edad o de no existir alguna causa de incapacidad (que en este caso se restringe al pródigo interdicto), le permite demandarla, está aludiendo al supuesto en que el contratante no ha solicitado la cédula de identidad ni consultado el Registro de Interdicciones del Conservador respectivo. En tal evento, el incapaz, debidamente autorizado por su representante, podrá demandar la nulidad del acto, pero el otro contratante no podrá reclamar la indemnización de los daños que ella le acarree, pues la causa de la nulidad emana de su propia negligencia ${ }^{81}$.

Un caso similar se aprecia si se celebra un contrato con un incapaz, con omisión de las formalidades habilitantes exigidas por el legislador, ya que si el que contrató con el incapaz demanda la nulidad y éste se excepciona alegando su incapacidad o el mismo incapaz la solicita por tal motivo, quien contrató con él no podrá pedir la restitución de lo dado o pagado en razón del contrato, a menos que el incapaz se hiciere más rico. Tal solución, prevista en el artículo 1688 del Código Civil, constituye una medida de protección del incapaz que altera el efecto restitutorio de la nulidad y que, por lo mismo, priva al perjudicado con ella solicitar la indemnización de los daños que ésta le ocasione, toda vez que la exigencia de formalidades habilitantes es impuesta por ley y ésta se presume conocida por todos. En consecuencia, su omisión evidencia al menos la culpa, si no el dolo, del contratante capaz.

Finalmente, si el contratante capaz induce maliciosamente al incapaz a celebrar un contrato para aprovecharse de él, resulta claro que la nulidad impetrada por el segundo invocando el dolo vicio, llevará aparejada como prestación complementaria la indemnización de los daños que ella le cause, dado que este supuesto puede reconducirse a los artículos 2314 y 2329 de nuestro Código Civil que imponen la obligación de indemnizar a todo aquel que ha inferido un daño a otro, dolosa o culposamente.

\section{- Indemnización de daños por falta de objeto o de causa}

La tercera hipótesis en que procede la indemnización es en aquellos casos en que el objeto del acto o contrato no existe en todo o en parte, y la ineficacia acarree daños al contratante que confió en su validez, motivo por el cual quien generó dicha confianza deberá indemnizarlos. Es precisamente el supuesto que analizó lhering ${ }^{82}$ al formular la teoría de la culpa in contrahendo a partir de la

80 Así GarCía (1991), pp. 183-184. Asúa (1989), pp. 263-265.

81 Baraona (2012), pp. 94-95.

82 VON IHeRING (2005), pp. 3 y ss. 
venta de una cosa extra commercium y de una herencia inexistente, regulada en los parágrafos 306 y 307 del $B G B$ hasta la reforma de 2002, y que la doctrina comparada ha denominado imposibilidad objetiva originaria de la prestación ${ }^{83}$.

Sin embargo, la moderna tendencia es desestimar que la imposibilidad originaria de las prestaciones pactadas afecte la validez del contrato, como lo revelan los artículos 3.1.3 de los PICC, 4:102 de los PECL, II. 7:102 del DCFR y 1301 de la $P M E^{84}$, pues se estima que es más acertado considerar válido el contrato y admitir una indemnización del interés positivo, dado que, en este caso, el cumplimiento específico carecería de sentido.

Nuestro Código ha contemplado la falta de objeto como supuesto de la pretensión indemnizatoria sólo en la compraventa, como lo revela el artículo 1814 que, en su inciso primero lo consagra como un supuesto de ineficacia y, en el inciso final, prevé la indemnización de daños. En efecto, aquél indica que "la venta de una cosa que al tiempo de perfeccionarse el contrato se supone existente y no existe, no produce efecto alguno", discutiéndose si ella acarrea la nulidad absoluta o la inexistencia ${ }^{85}$. El segundo, en tanto, señala que "el que vendió a sabiendas lo que en el todo o una parte no existía, resarcirá los perjuicios al comprador de buena fe", esto es, al que no conocía o no debía conocer la falta de objeto. Como se advierte, en el evento que la cosa no exista, este inciso permite vincular la ineficacia del contrato a la indemnización de daños complementaria, pero por el interés negativo, pues concurre junto a aquella, de modo que no se ubicaría en sede de incumplimiento ${ }^{86}$.

Pero un análisis más detenido, revela que dicha norma consagra una regla que resulta aplicable a cualquier supuesto de falta de objeto, porque lo que se sanciona es el comportamiento doloso de quien celebra el contrato, engañando a la otra parte ${ }^{87}$. Incluso puede extenderse a la falta de causa final, habida consideración que ésta es el motivo inmediato que justifica las obligaciones de las partes. Miradas las cosas desde esta perspectiva no se trataría de una norma restrictiva, sino que constituiría la manifestación de una regla general. Esta indemnización podría demandarse como una consecuencia de la ineficacia del acto por falta de objeto, sea que se abogue porque tal precepto consagra la

\footnotetext{
83 Véanse Asúa (1989), pp. 137. Cabanillas (1995), pp. 771 y 772.

84 Un completo análisis en FenOY (2017), pp. 473-785.

85 Para una visión panorámica de esta clásica discusión véase SAN MARTín (2015), pp. 745-784.

86 Sin embargo, ello no impide que tal anomalía pueda proyectarse a la fase de ejecución, bajo la figura de la resolución por incumplimiento en la causal frustración del interés del acreedor. Volveremos sobre este punto en el último apartado de este trabajo a propósito de la confluencia entre la indemnización precontractual y contractual.

87 Baraona incluso extiende la aplicación de esta norma al objeto ilícito (BARAONA (2012), p. 95).
} 
inexistencia o la nulidad absoluta, dado que, independientemente de tal debate, se ha generado en el contratante la legítima confianza de la validez del contrato, frustrándose su expectativa, lo que hace procedente, indiscutiblemente, la indemnización del interés negativo.

\section{- Indemnización de daños por objeto ilícito o causa ilícita}

Un cuarto supuesto en que cabe preguntarse si procede la indemnización de daños derivada de la nulidad, es aquel en que ella encuentra su fundamento en el objeto o causa ilícita, pues el análisis que en este caso debe realizarse, difiere del que acometimos en el párrafo precedente a propósito de la falta de objeto y causa, dado que requiere efectuar disquisiciones jurídicas distintas.

En lo que respecta a estos supuestos, el Código Civil contempla dos normas a propósito de la nulidad absoluta que, interpretadas a contrario sensu, evidencian que el contratante que ignoraba la existencia de objeto o causa ilícita, esto es, estaba de buena fe, podrá acompañar a la nulidad, la indemnización, invocando el dolo del otro contratante que conocía o debía conocer la existencia de aquellas. En efecto, el artículo 1468 prescribe que "no podrá repetirse lo que se ha dado o pagado por un objeto o causa ilícita a sabiendas", sancionando así al contratante doloso, pues si bien estará obligado a restituir lo que recibió, no podrá solicitar la devolución de lo que dio o pagó ni, en lo que aquí interesa, una indemnización derivada de la nulidad. De otro lado, el artículo 1683 reitera la máxima del nemo auditor propriam turpitudinem allegans, al indicar que no puede demandar la nulidad absoluta el que celebró el contrato "sabiendo o debiendo saber el vicio que lo invalidaba", entendiéndose que exige el conocimiento real, personal y efectivo y no se refiere a aquel que debe tenerse en virtud de la ficción o presunción de conocimiento de la ley, establecida en el artículo $8^{\circ}$ del Código Civil ${ }^{88}$.

La pregunta que surge, entonces, es la siguiente: ¿existe algún caso en que uno de los contratantes podría no conocer o no debiera conocer que el acto adolecía de objeto o causa ilícita? La respuesta a esta interrogante, en principio, podría ser negativa, porque las causales de nulidad absoluta son de orden público e involucran el interés general de la sociedad, de modo que no dan lugar a la indemnización de daños, pues existe responsabilidad compartida ${ }^{89}$. Sin embargo, a nuestro juicio, existe una razón más simple y real: tales causales evidencian supuestos contrarios a la moral, a la ley y a las buenas costumbres, de modo que son fácilmente apreciables, porque tienen una dosis de inmora-

88 Por todos Alessandri y otros (2005), p. 333.

89 RodríGuez (1995), pp. 286 y 296. 
lidad, ilicitud o falta de decoro manifiestas que determinarán que, al menos uno de los futuros contratantes, se cuestione si es correcto contratar. Y es que resulta lógico que uno de ellos intuya que sea contrario a la ley someterse a una jurisdicción no reconocida por los tribunales chilenos (art. 1462), sujetarse a un pacto de sucesión futura (art. 1463), celebrar un contrato de venta de libros cuya circulación está prohibida o respecto de láminas, pinturas, estatuas obscenas o impresos condenados como abusivos de la libertad de prensa (art. 1466 parte segunda) y enajenar una cosa incomerciable, embargada por decreto judicial, sin la autorización o consentimiento del acreedor, o una especie cuya propiedad se litiga, sin el permiso de la contraparte o del juez que conoce del litigio (art. $1464 \mathrm{~N}^{\circ} 3$ y No 4).

Más discutida es la hipótesis de condonación de dolo futuro (art. 1465), toda vez que los involucrados podrían ignorar el alcance técnico de los principios de buena fe y de responsabilidad. Otro tanto acontece con aquellas referentes al contrato de juego o apuesta que se celebra en relación a un juego de azar, y los contratos prohibidos por ley (art. 1466 partes primera y tercera), dado que requieren un conocimiento efectivo de la ley, que es poco frecuente. Incluso en el supuesto de la enajenación de los derechos y privilegios que no pueden transferirse a otras personas (art. $1464 \mathrm{~N}^{\circ} 2$ ), ya que es muy probable que los involucrados en ella no conozcan esta circunstancia, como acontecerá tratándose del derecho de alimentos, del uso o la habitación. Por lo mismo, en todos estos casos, el conocimiento o el deber del conocimiento del vicio, resulta evidente si se trata de personas a las que, en virtud de su profesión, actividad, oficio o estudios, éste les era exigible, de modo que, si éste se configura, no sólo no podrán reclamar la nulidad, sino tampoco la indemnización derivada de ella, a la otra parte.

\section{- Indemnización de daños derivada de la actuación del falso procurador}

Otra hipótesis que podría dar lugar a la indemnización en sede precontractual es aquella en que el representante actúa sin poder o habiendo traspasado los límites de éste, deviniendo en un falsus procurator ${ }^{90}$. Y es que si el representado no ratifica el contrato, causará daños al contratante de buena fe que ha confiado en la validez del contrato que celebra con el representante de aquél. Recogiendo precisamente esta premisa, los códigos civiles más modernos y los PECL no sólo contemplan como medida de protección del otro contratante la facultad de revocación, sino que además tal indemnización, pero siguiendo diversos criterios.

90 Un acabado estudio de las hipótesis que pueden subsumirse en esta categoría en Rivero (2006), pp. 998-1008. 
Así, el artículo 1398 del Codice indica que quien representa a otro sin poderes o excede sus límites, es responsable de los daños que cause al tercero por haber confiado, sin su culpa, en la validez del contrato. Otro tanto acontece con el artículo 39 del Código suizo de Obligaciones, pues prevé que el mandatario indemnice los daños derivados de la invalidez del contrato si el mandante rehúsa expresa o tácitamente ratificar el mandato, a menos que pruebe que la otra parte ha conocido o debido conocer la ausencia de poder. Un fenómeno similar se advierte en el §179 (2) del $B G B$, dado que precisa que quien conocía la falta de poder debe indemnizar el interés positivo y aquel que ignoraba esta circunstancia, el interés negativo, agregando que ella no puede superar el importe del interés que la otra parte tiene en la eficacia del contrato. Finalmente, el artículo 3:204 de los PECL prescribe que, si no se produce la ratificación de lo actuado sin poder o extralimitando el conferido, el representante está obligado a pagar al tercero una indemnización que lo coloque en la misma situación en que éste se encontraría si hubiera actuado conforme a su poder de representación, salvo que el tercero conociera o no pudiera menos que conocer la falta de dicho poder.

Pero ¿estamos, efectivamente, ante un supuesto de indemnización precontractual? Esta interrogante tiene sentido si se considera que el Codice así la contempla y el $B G B$ admite tal posibilidad si el procurador sólo ignoraba la ausencia o extralimitación del poder conferido. Más aún si nuestro Código Civil, en lo que aquí nos interesa, establece en el artículo 2154 № 1 la responsabilidad del mandatario que ha excedido los límites del mandato respecto de terceros cuando no les ha dado "suficiente" conocimiento de sus poderes, sin precisar la naturaleza de tal responsabilidad ${ }^{91}$.

Resulta claro que la responsabilidad del falso procurador no puede ser contractual, dado que no se trata de un contrato en formación, pero, por otro lado, aún no es nulo ni inexistente, toda vez que puede ser ratificado. Tal consideración ha determinado que la doctrina comparada discuta si tal responsabilidad es precontractual o extracontractual ${ }^{92}$, debate que, si bien teóricamente es interesante, en términos prácticos se diluye en aquellos ordenamientos jurídicos como el nuestro, en que la tesis preponderante es que la responsabilidad precontractual se rige por el estatuto de la extracontractual ${ }^{93}$.

\footnotetext{
91 Por todos Stitchkin (2008), pp. 378-380; quien precisa que la expresión "suficiente" exige que el mandatario exhiba sus poderes completos y, en lo posible, con las instrucciones que le haya dado el mandante (STITCHKIN (2008), p. 385).

92 Una visión panorámica en Rivero (2006), pp. 1011-1015.

93 Por todos Barros (2006), pp. 1003 y ss. Domínguez y otros (1998) y Domínguez (2005), pp. 305-311.
} 
Y es que si bien se ha abogado por la naturaleza extracontractual de la responsabilidad derivada de la infracción del artículo $2154 \mathrm{~N}^{\circ} 1^{94}$, parece claro que, si el falso procurador causa daños al otro contratante, la indemnización que descansará en la ineficacia por falta de consentimiento y, por consiguiente, debe ponerlo en la situación más parecida a aquella en que se encontraría si no hubiera contratado. Por lo mismo, a nuestro juicio, esta hipótesis si bien se encuadra en el supuesto de defraudación a la confianza, derivada de la actuación irregular de quien contrata a nombre de otro sin estar autorizado, independientemente que se conciba como un supuesto de responsabilidad objetiva por riesgo creado $a b$ initio ${ }^{95}$ o subjetiva, constituye un caso de indemnización precontractual.

\section{- Indemnización de daños en caso de pérdida de la facultad de anular el contrato: la renuncia o prescripción de la acción de nulidad}

El último supuesto de este grupo de casos en que tendría lugar la indemnización de daños precontractual, es aquel en que el legitimado para interponer la acción de nulidad renuncia a ella, convalidándola, o tal acción simplemente prescribe. Constituyen hipótesis controvertidas, toda vez que, en principio, se trataría de una indemnización contractual, pues como consecuencia de la renuncia al ejercicio de la acción de nulidad o la prescripción de ella, el contrato se mantiene. Con todo, un destacado sector de la doctrina comparad ${ }^{96}$, al igual que los PECL y el DCFR, contemplan tal indemnización en la fase precontractual, de modo que resulta necesario determinar cuál sería la hipótesis específica en que ella tendría lugar en ordenamientos jurídicos como el nuestro.

En efecto, los artículos 4:117(2) de los PECL y II.7:214 del DCFR establecen la siguiente regla: la parte que teniendo derecho para anular un contrato no $l o$ ejerce o lo ha perdido, porque no lo ha comunicado en un plazo razonable o lo ha confirmado, puede reclamar una indemnización de daños, limitada a las pérdidas sufridas como consecuencia del error, dolo, intimidación, beneficio excesivo o ventaja injusta ${ }^{97}$. Una lectura preliminar de esta disposición podría

\footnotetext{
94 STITCHKIN (2008), p. 384, destacando que responde porque existe culpa o dolo al dejar en ignorancia a su contraparte o inducirla a contratar atendiendo a una condición jurídica distinta a la que aparenta o manifiesta.

95 Postulando la responsabilidad objetiva por riesgo creado del falso procurador Rivero (2006), pp. 1015-1063.

96 Cossío (1955), pp. 365-372. Morales (1982), p. 603. García (1991), pp. 208-211. Cabanillas (1995), pp. 768-769 y 775. De Verda (2006), p. 777. García y Otero (2010), pp. 47-48. Jerez (2011), pp. 293295 y BARAONA (2012), p. 91.

97 Los PICC, en cambio, si bien regula la pérdida del derecho a dar por anulado el contrato en el artículo 3.2.10, no otorgan al contratante perjudicado la facultad de solicitar la indemnización en tal caso.
} 
inducir a pensar que ella no tendría cabida en nuestro sistema, pues el Código Civil no contempla la facultad de demandar extrajudicialmente la nulidad, la obligación de comunicarla a la contraparte en un plazo razonable o la posibilidad de confirmar la nulidad absoluta. Sin embargo, la frase no lo ejerce o lo ha perdido, contenida en los preceptos antes aludidos, resulta de utilidad, dado que es aplicable a aquellos casos en que el perjudicado renuncie a demandar la nulidad relativa o hubiere prescrito la acción para impetrar la nulidad relativa o absoluta, porque transcurrió, respectivamente, el plazo previsto en los artículos 1691 y 1683 . A ello se agrega que no se trata de una hipótesis extraña al legislador, pues en el artículo 1353 indica que el partícipe que no quisiere o no pudiere intentar la acción de nulidad o rescisión, conservará los otros recursos legales que para ser indemnizado le correspondan.

Conferirle el derecho al acreedor perjudicado para que demande la nulidad resulta lógico, si se considera que la pretensión indemnizatoria es distinta e independiente de aquella, circunstancia que explica que esté legitimado para demandar daños quien no esté facultado para demandar la nulidad. Lo discutible es que en ambos supuestos el contrato se mantiene, dado que tanto la renuncia al ejercicio de la acción de nulidad como su prescripción, conllevan su saneamiento ${ }^{98}$, de modo que la única indemnización que debería poder demandarse es la contractual, pues la precontractual quedaría absorbida por la mantención del contrato. Lo cierto es que, a pesar de ello, pueden existir pérdidas derivadas de alguna causal de nulidad que no hayan sido resarcidas con la subsistencia del contrato, perjudicando al contratante que padeció el vicio, razón por la cual los referidos artículos de los PECL y del DCFR adoptan una fórmula intermedia entre el interés positivo y negativo, contemplando el resarcimiento de aquellas ${ }^{99}$.

Piénsese, por ejemplo, en el caso que un corredor de propiedades adquiere un terreno confiando en la declaración del vendedor que está libre de gravámenes, y posteriormente descubre que está sujeto a una servidumbre de paso que lo obliga a gastar \$5.000.000 para desviar el paso, caso en el cual reclamará el importe del gasto realizado, pues no tiene otra forma de recuperar esa pérdida si mantiene el contrato, deviniendo en daño. Una situación similar se advierte si un sujeto engaña a otro para que éste le venda 50 acciones a $\$ 2.000$, esto es, por un total de $\$ 100.000$, en circunstancias que su valor real es de $\$ 4.000$, de modo que podría haber obtenido un total de \$200.000 transándolas en la

98 La diferencia es que en la renuncia existe un propósito deliberado de conservar el contrato, en tanto, la prescripción de la acción puede encontrar su causa en la negligencia del perjudicado.

99 Díez-Picazo y otros (2002), p. 245. 
Bolsa, y posteriormente el valor de la acción baja a $\$ 1.000^{100}$. En esta hipótesis, el vendedor solicitará al comprador la pérdida causada por el dolo que equivale a $\$ 2.000$, si prueba que podría haber vendido las acciones a $\$ 4.000$, ya que si anulara el contrato sólo recuperaría \$1.000, debiendo soportar una doble pérdida que no resulta justa: aquella derivada del engaño del otro contratante y la ocasionada por la baja de la acción en el mercado bursátil.

Nuevamente nos encontramos ante un supuesto que no está expresamente previsto en nuestro Código Civil y que, por lo mismo, exige construir una regla equitativa que pueda reconducirse a las normas contenidas en el Título 35 de su Libro IV. La particularidad de este caso es que, a diferencia de las anteriores, denota un cambio de enfoque de la perspectiva en que se conciben los vicios del consentimiento, ya que no se restringe a un problema de voluntad defectuosa, sino que evidencia un problema de daños que se traduce en un contrato económicamente desventajoso ${ }^{101}$. A ello se agrega que propende a la reparación integral en sede precontractual a través de una partida indemnizable que, si bien no se había considerado hasta ahora, es plenamente admisible, pues tiene por propósito resarcir pérdidas originadas en una causa de nulidad que no pueden ser absorbidas por la mantención del contrato y que de no indemnizarse enriquecerían injustamente al otro contratante.

Examinado este último supuesto es posible formular una regla general a propósito de la indemnización precontractual tratándose de la celebración de un contrato inválido, ampliando el catálogo que hasta la fecha ha enunciado la doctrina nacional y admitiendo como medida general el interés negativo: la indemnización de daños será procedente cuando éstos no se reparen con la sola invalidación del acto, en aquellos casos en que el contrato se ha celebrado con malicia o negligencia de una de las partes ${ }^{102} y$ en el evento en que se ha extinguido la facultad de anular el contrato, comprendiendo, en este último caso, un daño que se encuentra entre el interés negativo y positivo.

\section{iii. Vulneración del deber de confidencialidad}

El deber de confidencialidad surge como consecuencia del deber de lealtad en las negociaciones preliminares, y es aquel según el cual quien, en el curso de ellas, ha conocido datos ${ }^{103}$ cuya divulgación perjudicaría a la otra parte, debe

\footnotetext{
100 El primer caso es similar al que citan los comentarios del PECL (LANDo y BeALE (2003), p. 409) y el segundo, lo formulan en términos semejantes Thur y Thilo, citados por GARCía (1991), p. 210, nota 12.

101 Morales (2011), pp. 409 y 411.

102 Véanse Rodríguez (1995), p. 296. Baraona (2012), pp. 88-97.

103 Benatti (1963), p. 43. García (1991), p. 54. Cabanillas (1995), p. 784. Barrientos (2008), p. 100. QuesaDA (2011), p. 99, han precisado que deben obtenerse "a causa de los tratos" y no "con ocasión de ellos".
} 
guardar la debida reserva o secreto, se celebre o no el contrato, y no puede utilizarla en beneficio propio. Por consiguiente, su infracción acarreará daños a la otra parte que deben resarcirse, motivo por el cual constituye un supuesto de indemnización precontractual previsto en los artículos 2.1.16 de los PICC, 2:302 de los PECL, II.- 3:302 del DCFR, 12 de los PLDC y 1112-2 del Código Civil francés ${ }^{104}$.

Así ocurriría si un individuo le ofrece a una empresa de computadores un nuevo chip que aumenta su velocidad, y durante las negociaciones le proporciona información confidencial sobre su diseño, retirándose al mes siguiente de las negociaciones, aduciendo que el precio era muy elevado y entregándole a su proveedor habitual tal información para que lo fabrique a un precio inferior del que habría pagado al oferente inicial ${ }^{105}$. Un supuesto similar se producirá si lo que se revela es la situación financiera de una empresa, la cartera de clientes, la licencia de tecnología, asesoría o soporte técnico de un aparato o dispositivo o el diseño de marcas o patentes, obtenida con ocasión de los tratos preliminares.

Con todo, como no existe un deber general de confidencialidad, para que estemos ante este supuesto se requiere que el carácter secreto o reservado de la información resulte expresamente de la declaración de quien así la considere o se desprenda de determinadas circunstancias, debiendo atenderse al tipo de información, la naturaleza y fin del contrato y las características del receptor de la información, toda vez que puede ser un potencial competidor en la producción del bien o servicio sobre el que se está suministrando la información ${ }^{106}$.

El alcance de la indemnización en este supuesto difiere de los anteriores, toda vez que es más amplia, pues la revelación de la información a un tercero o su utilización en beneficio propio generan daños adicionales e incluso un enriquecimiento injustificado que no quedan cubiertos por el interés negativo ${ }^{107}$. Por tal motivo, la pretensión indemnizatoria debe traducirse en la recuperación de los beneficios ilícitamente obtenidos por quien infringió el deber de confidencialidad y en una indemnización independiente, regla que consagran, respectivamente, el artículo 2.1.16 de los PICC y los artículos 2:302 de los PECL, II.-3:302 del DCFR y 12 de los PLDC.

Nuestro Código Civil no contempla el deber de confidencialidad, pero la doctrina nacional ha reconocido su existencia, amparándose en el principio

104 Con todo, se ha sostenido su naturaleza extracontractual (GARCía (1991), p. 54. Asúa (1989), pp. 261-262).

105 Este es precisamente el ejemplo que analiza GarCía (2012), pp. 269-275.

106 Díez-Picazo (2007), p. 314. García (2012), p. 270.

107 Díez Picazo y otros (2002), p. 200. 
de buena fe que debe imperar durante la fase precontractual ${ }^{108}$, de modo que la reparación de los perjuicios derivados de su infracción puede reconducirse a los artículos 2314 y 2329 y al enriquecimiento injustificado para obtener la restitución de los beneficios indebidos, institución que si bien no está regulada en el Código, ha sido admitida plenamente por la doctrina y jurisprudencia nacionales ${ }^{109}$.

\section{b. Infracción del deber de información}

Un segundo deber que se advierte durante la fase precontractual es el deber de información ${ }^{110}$, consagrado expresamente en los artículos $3^{\circ}$ b), 14, 30, 32 y 35 de la Ley No 19.496 sobre Protección de los Derechos de los Consumidores, en el artículo 10 de la Ley N 20.584 que regula los Derechos y Deberes que tienen las personas en relación con acciones vinculadas a su atención de salud, en el artículo 514 del Código de Comercio relativo al contrato de seguro ${ }^{111}$, en los artículos $6^{\circ}$ y $7^{\circ}$ de la Ley $N^{\circ} 20.606$ sobre composición nutricional de los alimentos y su publicidad ${ }^{112}$ e indirectamente tratándose de la indemnización prevista por incumplimiento del saneamiento de la evicción en los artículos 1840, 1930 inciso cuarto, 2188 del Código Civil y de los vicios redhibitorios en los artículos 1861, 1933, 2192 y 2203 de dicho cuerpo normativo.

Desde luego, el problema de determinar la existencia de este deber no se presenta en los casos en que se encuentra tipificado por ley (deberes típicos), sino en aquellos supuestos en que no lo está (deberes atípicos) ${ }^{113}$ y su fundamento se reconduce a la buena $\mathrm{fe}^{114}$, debiendo el juez establecer su existencia, atendiendo a diversos factores. Tales son, entre otros, la simetría de la relación contractual, la complejidad, novedad y riesgo que envuelve el contrato, el costo

\footnotetext{
108 BarRientos (2008), pp. 100-109. Boetsch (2011), p. 142. Distinta es la situación del artículo 42 NNo $^{\circ}$ de la Ley $N^{\circ} 18.046$ y los artículos 164 y 165 de la Ley № 18.045 que contemplan expresamente ese deber.

109 Véase principalmente PeÑAlLILlo (1996), pp. 32-40. CÉSPedes (2004), pp. 9-33.

110 Barros (2006), pp. 1014-1027. De la Maza (2011), y Barrientos (2015a) y (2015b). Un completo estudio de sus elementos constitutivos en Fabre-Magnan (1992), pp. 118 y ss.

111 Un detallado análisis en Barrientos (2015 a). Ríos (2014). Barrientos (2015 b).

112 En efecto, tales preceptos establecen el deber de los fabricantes, productores, distribuidores e importadores de alimentos de informar en los envases o etiquetas de los alimentos destinados al consumo humano los ingredientes que contienen, incluyendo todos sus aditivos (expresados en orden decreciente de proporciones), y su información nutricional y los contenidos de energía, azúcares, sodio y grasas saturadas y los demás que el Ministerio de Salud determine.

113 Terminología utilizada por De LA MAZA (2010a), pp. 67 y ss.

114 Entre otros, Morales (1982), p. 646, Gómez (1994), pp. 12 y ss. Rojo (1994), p. 255. Díez-Picazo (2007), pp. 312-313. DeVerda (2006), pp. 762-763. Barros (2006), pp. 1015 y 1017, De La Maza (2008). Un tratamiento más detallado en De LA MAZA (2010a), pp. 67-371.
} 
de la obtención de la información, la protección de la ignorancia de una de las partes por una norma legal, la imposibilidad de autoinformarse, la legítima confianza suscitada por el otro contratante o por datos objetivos de la realidad y la existencia de intereses contrapuestos o comunes de las partes ${ }^{115}$. De hecho, al menos el artículo 4:107 de los PECL, ha indicado que debe considerarse, especialmente, si quien proporciona la información poseía una pericia especial, el costo de obtener tal información, si el destinatario de la información hubiera podido razonablemente adquirirla por sí mismo y la aparente importancia que la información tenía para éste ${ }^{116}$.

La infracción de este deber precontractual se advierte indiscutiblemente en dos supuestos: aquellos en que una parte le proporcionó, culpablemente o no, a la otra, una información incorrecta (acción), y aquellos en que dolosamente no se la proporcionó (omisión), advirtiéndose diferentes alternativas de protección del acreedor, quien podrá optar, según el caso, entre los medios de tutela contractuales y precontractuales ${ }^{117}$, manteniendo el contrato (a través de su adaptación, la rebaja del precio o la indemnización de daños precontractual o contractual) o desvinculándose (ejerciendo la acción redhibitoria o la resolutoria).

Y es que, en lo que a esta investigación interesa, la vulneración del deber precontractual de información puede determinar: a) la existencia de un vicio del consentimiento del contratante no informado -específicamente error o dolo-, b) la existencia de declaraciones inexactas no constitutivas de error y c) la vulneración de las obligaciones de advertencia. Si bien el perjudicado podrá reclamar la indemnización de daños derivados de un contrato inválido (primer y tercer supuesto) o de un contrato válido, pero desventajoso (segundo y tercer supuesto), surge la necesidad de determinar si tal indemnización es precontractual o contractual y si puede ejercerse en forma complementaria o autónoma.

Excluimos de este catálogo al dolo incidental, pues determina que se celebre el contrato en condiciones más desventajosas, acarreando como consecuencia una indemnización contractual, ya que como no se configura un vicio del consentimiento, no puede aniquilarse el contrato a través de la nulidad relativa, manteniéndose ${ }^{118}$. Tal es el alcance que debe dársele a la indemnización prevista en el inciso segundo del artículo 1458 del Código Civil, perfilándose como un caso indiscutido de indemnización contractual autónoma que encuentra su

115 Gómez (1994), pp. 89-97. Basozabal (2009), pp. 699-702 y 705-708 y De la MaZa (2010a), pp. $207-347$.

116 Un análisis de estos criterios en De LA MAZA (2008), pp. 60-68.

117 Rojo (1994), pp. 142-147. Basozabal (2009), pp. 662-663. De la Maza (2010a), pp. 268-273.

118 Una aproximación a este tópico en la doctrina nacional en PRADO (2015b). 
fundamento en la infracción de deberes secundarios de conducta que causan daño al acreedor ${ }^{119}$, específicamente, en el deber precontractual de información.

También prescindiremos de la indemnización que procede en aquellos casos en que el obligado a informar que la cosa puede ser evicta no lo hace, habiéndose pactado que la entrega transfiere el dominio de ésta o que no debe estar gravada con derechos en favor de terceros, dado que en este caso estaremos ante el incumplimiento de la obligación de entrega, de modo que la indemnización será contractual. Una hipótesis distinta se verifica en aquellos supuestos en que tal obligación no es modelada por las partes y el acreedor es privado de la cosa por sentencia judicial, dado que resulta aplicable el régimen especial de garantía por evicción, específicamente los artículos 1840, 1930 inciso cuarto, 2188 del Código Civil, de modo que no existirá incumplimiento. Estos preceptos que prevén la indemnización en favor del otro contratante no la asocian a la nulidad, de modo que como no concurre junto a ella podría pensarse que su naturaleza tampoco es precontractual. Pero la extinción del contrato como consecuencia de la privación de la cosa puede conducirnos a la conclusión contraria. Volveremos sobre este punto.

\section{- Indemnización por infracción del deber precontractual de información derivada del dolo vicio y del error}

Claro está que la infracción del deber de información puede ser deliberada o culposa y determinará, respectivamente, la existencia de dolo o error, viciando el consentimiento del destinatario. Así acontecería si el contratante obligado a informar omitiera indicar determinados antecedentes al otro que, de haberlos conocido, no hubiera contratado, como el año de fabricación de la cosa objeto del contrato, la autoría de una determinada obra, las cualidades específicas ausentes en la cosa o defectos de los que ella adolece, configurándose una reticencia dolosa; o bien, efectuara declaraciones intencionalmente incorrectas sobre tales antecedentes. De otro lado, es posible que la vulneración del deber de información encuentre su causa en la negligencia del contratante que no informó correctamente, porque si bien facilitó los datos antes referidos, éstos son falsos u omitió aquellos que eran ciertos, determinando un error sustancial en el otro.

La única diferencia entre la infracción dolosa o negligente es que, en el primer caso, cualquier información puede ser, en principio, objeto de tal deber, pues junto a las presuposiciones del contrato puede sumarse aquella información que haya determinado al deceptus a contratar, ampliándose así el ámbito de la

119 LÓPEZ (2015), pp. 235-244. 
información relevante. Tratándose del error, en cambio, es información relevante aquella que de alguna manera se ha incorporado al contrato-como por ejemplo que un predio no es urbanizable o que no puede dársele un destino comercial-, la que deberá suministrarse en la medida que la buena fe así lo exija ${ }^{120}$.

Lo cierto es que, en ambos casos, el perjudicado con la falta de información o información defectuosa podría demandar la indemnización conjuntamente con la nulidad o en forma exclusiva, porque la infracción del deber de información es imputable a la culpa o dolo de quien debió suministrarla ${ }^{121}$. En el evento que demande indemnización complementaria, no cabe duda que ella será precontractual y cubrirá el interés negativo, porque es complementaria a la nulidad.

La interrogante, entonces, se suscita respecto de la pretensión indemnizatoria autónoma derivada de la infracción del deber precontractual de información que nuestro Código Civil regula en los artículos 1861'22, 1933, 2192 y 2203, a propósito de la compraventa, arrendamiento, comodato y mutuo, respectivamente, y que es, por lo demás, el único caso de indemnización que contempla expresamente a propósito de tal vulneración dolosa (si conocía los vicios y no los declaró) o culposa (si los vicios eran tales que haya debido conocerlos por razón de su profesión u oficio o si la otra parte no haya podido con mediano cuidado conocerlos y precaver los perjuicios).

En efecto, inicialmente se sostuvo que como se infringía un deber precontractual de información, la indemnización alcanzaba el interés negativo, pues ésta era la regla general en esa fase ${ }^{123}$. Luego se generalizó la idea según la cual en aquellos casos en que el deber precontractual de información se proyecta sobre el contenido del contrato y genera problemas de incumplimiento, es más adecuado atraer la indemnización del daño a la responsabilidad contractual, pues también se infringe un deber de prestación ${ }^{124}$. Pero a nuestro juicio, puede

\footnotetext{
120 De La Maza (2010a), pp. 282 y 283.

121 En el derecho inglés, en cambio, se admite la indemnización por declaraciones falsas o inexactas, sean intencionales (tort of deceit) o no (tort of negligence) por el interés negativo, más estricta en este último caso, pues sólo cubre los daños razonablemente previsibles para el infractor. Incluso existe una acción en la Sección 2 (1) de la Misrepresentation Act de 1967, aunque no sea fraudulenta, a menos que el declarante pruebe que tuvo motivo razonable para creer que los hechos declarados eran verdaderos (CARTWRIGHT (2007), pp. 162-164).

122 Admitida por la doctrina y jurisprudencia recientes. Una visión panorámica en LóPEZ (2016), pp. 660-666.

123 VON IHERING (2005), pp. 33 y ss.

124 Morales (2010), pp. 90-91. A tal efecto indica que es en el marco del contrato en el que se produce el daño y que éste justifica la puesta en riesgo de los bienes dañados, de modo que debe ofrecer el criterio para distribuir el riesgo que el daño produzca. Tal idea es seguida por AsúA (1989), p. 261. Gómez (1994), p. 44. Cabanillas (1995), p. 777. De la Maza (2010a), pp. 273-274. García y Otero (2010), p. 56. OVIEDO (2014), pp. 251-252.
} 
existir una tercera perspectiva para abordar este problema, cual es, sostener que se trata de una indemnización precontractual, toda vez que se ha infringido un deber de información durante esa etapa, que efectivamente se proyecta en el contenido del contrato y determina un cumplimiento defectuoso, pero que transitará desde la fase precontractual a la contractual, sólo si el acreedor decide demandarla como tal ${ }^{125}$.

Y es que, si bien podría pensarse que, en el evento que la infracción del deber de información se incorporara en el contenido del contrato, sería más conveniente encauzar la pretensión indemnizatoria en sede de incumplimiento e instar por la indemnización contractual, no siempre lo será. Así ocurriría en aquellos casos en que resulte difícil probar con certeza el importe del interés positivo que equivaldría al cumplimiento del contrato, más no la cuantía del interés negativo que se reconduce a no haberlo celebrado ${ }^{126}$. Volveremos sobre este punto a propósito de la confluencia de la indemnización precontractual y contractual.

\section{- Indemnización por infracción del deber precontractual de información derivado de declaraciones inexactas que no constituyen error.}

De lo dicho hasta acá podría pensarse que la infracción del deber precontractual de información sólo puede materializarse a través de un vicio del consentimiento que acarree la nulidad del negocio celebrado. Sin embargo, también puede determinar la existencia de un contrato válido, pero económicamente desventajoso para uno de los contratantes, porque el otro ha realizado declaraciones incorrectas o inexactas que no configuran un error en la contraparte, procediendo una indemnización en favor de quien no fue informado ${ }^{127}$.

Tal supuesto está expresamente regulado en el artículo 4:106 de los PECL, pues señala que aquella parte que celebra un contrato basándose en una información incorrecta dada por la otra, podrá exigir la indemnización en los términos del artículo 4:117, esto es, por la pérdida causada por la información incorrecta, incluso cuando tal información no le haya provocado un error esencial en los términos del artículo 4:103 ${ }^{128}$; salvo que la parte que proporcionó la información tuviera motivos para creer que era correcta. Se trata, por consiguiente, de una indemnización que procede con independencia de la nulidad y que se sitúa a

\footnotetext{
125 Un análisis más extendido de este tópico en LópEZ (2016), pp. 659-683.

126 PANTAleÓn (2011), pp. 920-921.

127 Visintini (1972), pp. 91-154, y 251-324. Rojo (1994), pp. 287-288. Fabre-Magnan (1992), pp. 466507, Gómez (1994), pp. 29-50. Barros (2006), pp. 1015-1016. García y Otero (2010), pp. 46-53.

128 Tal error faculta al contratante para anular el contrato, salvo que éste fuera inexcusable o hubiera asumido el riesgo del error o debiera soportarlo conforme las circunstancias.
} 
medio camino entre el interés positivo y el negativo, toda vez que comprende la diferencia entre la posición en que el contratante informado incorrectamente se encuentra actualmente y aquella en que estaría si se le hubiera proporcionado la información correcta, agregándose las pérdidas que superen esa diferencia.

Tal sería el caso si el vendedor le informa al comprador que el vehículo que le entrega tiene $50.000 \mathrm{~km}$ y su precio asciende a $\$ 10.000 .000$, en circunstancias que el valor real, de acuerdo al kilometraje, era de \$8.500.000, y al manejarlo, el tubo de escape se pulveriza, destruyendo la maleta del automóvil que contenía diversos materiales de construcción. En tal hipótesis, de conformidad al precepto que venimos comentando, el comprador podrá solicitar una indemnización de \$1.500.000 y las pérdidas que le ocasionó la destrucción de la maleta y de lo que se encontraba en su interior ${ }^{129}$. Y es que resulta lógico que asuma el riesgo de la información incorrecta quien la proporcionó negligentemente, pues no ha tenido el menor cuidado en verificar su veracidad y ha determinado que el otro contratante adopte decisiones económicas en razón de ella. Distinto es el supuesto en que las declaraciones efectuadas envuelvan una promesa de verdad y ésta no se cumpla, puesto que en tal caso estaremos ante las denominadas garantías contractuales, trasladándonos a la fase de incumplimiento, dado que su inobservancia faculta al acreedor para demandar la indemnización de daños exclusiva, pero esta será de naturaleza contractual ${ }^{130}$. De allí que los PECL las regulen separadamente en el artículo 6:101 bajo el epígrafe declaraciones de las que nacen obligaciones contractuales.

Claro está que la indemnización por declaraciones inexactas que no constituyen error no se encuentra expresamente regulada en nuestro Código Civil, pero nada obsta a que ella pueda reclamarse invocando la infracción del deber precontractual de información y reconducirse a las reglas contenidas en el Título 35 del Libro IV, toda vez que ha existido un ilícito que causa daño a uno de los contratantes, imputable a la negligencia del otro ${ }^{131}$, cuyo importe puede determinarse según la fórmula contenida en el artículo 4:117 de los PECL. Descartar su procedencia equivale a trasladar los riesgos de la información defectuosa desde el contratante que ha sido negligente en entregarla, al que experimenta daños derivados de tal inexactitud, lo que resulta inequitativo y contrario al principio de responsabilidad y reparación integral.

De hecho, esta especial categoría puede servirnos para reconducir la indemnización derivada de la infracción de obligación de informar que la cosa puede

129 Un ejemplo similar es el que citan Lando y Beale (2003), pp. 357 y 358.

130 López (2015), pp. 228-234. Para una distinción de los medios de tutela entre las garantías y declaraciones contractuales véanse Barros y Rojas (2010), p. 514.

131 BarRos (2006), p. 1034. 
ser evicta, pues, como ya lo apuntamos, ella no va asociada a la nulidad del contrato, sino que éste se extingue como consecuencia de la privación judicial de la cosa, motivo por el cual la excluimos del catálogo de casos expuestos en el apartado anterior. Por consiguiente, sería autónoma, pero no cubriría exclusivamente el interés negativo, ya que, si bien deja al contratante perjudicado en la situación en que se encontraría de no haber celebrado el contrato, comprende, por regla general, el valor de los frutos que el comprador hubiere sido obligado a restituir al dueño (art. $1847 \mathrm{~N}^{\circ} 3$ ) y el aumento de valor que la cosa evicta haya tomado en poder del comprador (art. 1847 № 5), con el propósito de propender a su reparación integral.

\section{- Indemnización por vulneración de obligaciones de advertencia.}

Un tercer caso de indemnización derivada de la infracción del deber precontractual de información, tiene lugar en aquellos casos en que los sujetos que negocian un contrato de prestación de servicios vulneran una obligación de advertencia, esto es, una especie de obligación de información precontractual que no tiene por propósito prevenir asimetrías informativas, sino permitir que quienes negocian concreten en el más alto grado el servicio a prestar y el precio, encauzando la relación precontractual. En consecuencia, resultan exigibles si ellos conocen o tienen razón para conocer la información sobre la que deben advertir, eximiéndosele de ellas en el caso que el usuario del servicio haya accedido a ésta por otra vía ${ }^{132}$.

La especial configuración de estas obligaciones justifica que las abordemos por separado, toda vez que son más exigentes que las obligaciones de información, pues el deudor debe proporcionar una información objetiva, precisando el riesgo o peligro que se derivará de desestimarla, antecedente que permitirá al acreedor decidir si resulta conveniente contratar ${ }^{133}$. Piénsese, por ejemplo, en un contrato de depósito o almacenamiento en que el prestador advierte al prestatario que las bodegas en las que custodiará o almacenará determinadas frutas para exportación no se encuentran en condiciones para refrigerarlas a la temperatura adecuada o en que el prestador señale al cliente que tales frutas tienen una concentración química que podría dañar los contenedores en que ellas se almacenarán o custodiarán.

Si bien tales obligaciones están reguladas expresamente en los artículos IV.C.2:102 del DCFR y 1:103 de los Principios Europeos sobre Contratos de Servicios, nada impide su procedencia en nuestro ordenamiento jurídico, pues

132 Alonso (2012), pp. 1, 6 y 8.

133 Fabre-Magnan (1992), pp. 379-383. Alonso (2012), p. 10. 
pueden vertebrarse a partir del deber precontractual de información que debe imperar en la fase precontractual y que dimana de la buena fe contractual, cuya consagración normativa se encuentra en el artículo 1546. Y es que parece lógico que el futuro prestador deba advertir al futuro cliente o prestatario la posibilidad de no obtener un resultado que espera o que éste podría ser más oneroso o requerir más tiempo de ejecución que el previsto. Idéntico razonamiento subyace si se le exige al futuro prestatario advertir al prestador del servicio cualquier hecho inusual que pueda encarecer el servicio o alargar su ejecución en el tiempo.

La pregunta que surge, entonces, es la siguiente: ¿qué consecuencias lleva aparejada la infracción de esta obligación? Y la respuesta variará dependiendo si quien la vulnera es el prestador o el prestatario. En efecto, de acuerdo a tales preceptos, si quien infringe el deber de advertencia es el cliente, el prestador podrá demandar los daños derivados de la pérdida de la no ejecución del servicio y un reajuste del período que se requiere para el suministro del servicio, adaptando el contenido del contrato. En cambio, si quien incumple es el prestador del servicio, el cliente podría instar por el cumplimiento específico, exigiendo que el contrato se ejecute en los términos pactados, a menos que se demuestre que igualmente hubiera contratado de haber sido advertido, debiendo aceptar una modificación del mismo. Pero podría ocurrir que ni el cumplimiento ni la adaptación sean pertinentes, porque la inejecución de tal deber determinó la frustración del negocio, como acontecería si el prestador del servicio no advierte al cliente que los contenedores no pueden refrigerar la fruta a la temperatura requerida y ello ocasionara su putrefacción y pérdida, caso en el cual podría instar por la indemnización derivada de la infracción de la obligación de advertencia precontractual.

En este último supuesto, nuevamente debe determinarse si tal indemnización es precontractual o contractual. Con todo, tal como hemos descrito el problema, la pretensión indemnizatoria se sitúa en la fase de formación del contrato y puede encontrar su causa en la nulidad, si la omisión de advertir determina el engaño o el error del destinatario, asociándose a ella y deviniendo en complementaria. Sin embargo, la indemnización también puede derivar de la inexactitud de la advertencia que no provoca error vicio en el destinatario ni constituya dolo determinante, desligándose de la nulidad y situándose a medio camino entre el interés positivo y el negativo, pues alcanzará la diferencia entre la posición actual del contratante y aquella en que estaría si la advertencia hubiera sido correcta, agregándose las pérdidas que superen esa diferencia. Cuestión distinta es que, ante el mismo supuesto, el cliente o prestatario decida sustentar la pretensión indemnizatoria por infracción de una obligación de advertencia contractual, pues, en esa situación, estaríamos ante uno de los casos de confluencia entre ambas, tópico que abordaremos a continuación. 


\section{Confluencia de la indemnización precontractual y contractual: la opción del acreedor}

Como ha quedado de manifiesto en los apartados anteriores, existen ciertos supuestos en que puede demandarse la indemnización precontractual. Efectuada esta sistematización, cabe formular la siguiente interrogante: ¿puede confluir con aquella derivada del incumplimiento contractual? Y la respuesta es que depende del deber precontractual infringido y de la hipótesis concreta en que ello tiene lugar, dado que existirán casos en que tal indemnización reviste un carácter exclusivamente precontractual, algunas en que es indiscutiblemente contractual y otras en que el acreedor podrá proyectar la infracción de un deber precontractual a la fase contractual, optando por una u otra indemnización.

En efecto, tratándose de supuestos de infracción del deber de lealtad es posible advertir: (i) casos indiscutidos de indemnización precontractual (la celebración de un contrato inválido por vicios del consentimiento, falta de objeto o causa, objeto o causa ilícitos, incapacidad de uno de los contratantes o celebrado por un falso procurador cuyo poder no se ha ratificado), (ii) hipótesis que admiten particularísimas excepciones (la ruptura injustificada de las tratativas precontractuales), (iii) otras que están a medio camino entre el interés positivo y negativo (pérdida de la facultad de anular el contrato), (iv) supuestos que añaden al interés negativo la restitución de beneficios indebidos (vulneración del deber de confidencialidad), y (v) casos en que la indemnización precontractual confluye con la contractual. Tal es el caso de la indemnización derivada de la nulidad por error, dolo o falta de objeto del artículo del Código Civil, en el evento que el acreedor prefiera demandar la resolución por incumplimiento y la indemnización complementaria, en vez de la nulidad acompañada de la indemnización precontractual, subsumiendo tales causales de ineficacia en la resolución, si ellas determinan la frustración del interés del acreedor.

Un fenómeno similar se aprecia a propósito de la infracción del deber de información, toda vez que si bien existen casos en que ella se encuentra entre el interés positivo y negativo (no informar que la cosa puede ser evicta y declaraciones o advertencias inexactas que no constituyen error) y supuestos en que indiscutiblemente la indemnización es contractual (dolo incidental e incumplimiento de la obligación de transferir el dominio de la cosa o entregarla libre de gravámenes), también es posible que una misma hipótesis reúna los requisitos para impetrar la indemnización en sede precontractual o contractual. Así ocurre tratándose de la existencia de vicios redhibitorios y la infracción de las obligaciones de advertencia, mas no en las declaraciones contractuales, toda vez que el acreedor ejerció su opción antes de realizarlas, pues como ellas no envuelven una promesa de verdad, no se transforman en garantías contractuales y permanecen en la fase precontractual. 
En los supuestos de confluencia de indemnizaciones que venimos comentando, ¿podría el acreedor optar por una u otra? o ¿deberá solicitar siempre la indemnización precontractual si la infracción de un deber de esta naturaleza le ha causado daños? La respuesta a esta interrogante ciertamente supone determinar si debe reconocérsele al acreedor un derecho de opción entre la indemnización precontractual y contractual, tópico que ha sido abordado por los instrumentos de armonización del derecho de obligaciones y contratos, en términos más generales, con ocasión de la compatibilidad entre los medios de tutela precontractuales y contractuales, advirtiéndose soluciones diversas. En efecto, el artículo 3.2.4 de los PICC establece su incompatibilidad en caso de nulidad por error, la que se ha justificado indicando que estos últimos otorgan una protección más efectiva al acreedor y son más flexibles que la nulidad ${ }^{134}$. El artículo 4:119 de los PECL, en cambio, al igual que el artículo 49 de los $P L D C$, consagra la compatibilidad, pues indica que la parte que tenga derecho a intentar algún medio de tutela precontractual y, a la vez, pueda deducir uno contractual, podrá recurrir a cualquiera de ellos ${ }^{135}$. La regla es más confusa en el DCFR, toda vez que el artículo II.-3:109 (3) descarta la compatibilidad a propósito de la infracción de deberes de información y el artículo II.-7:214 relativo a los daños por pérdidas, parece consagrar la regla contraria.

Como se ha indicado precedentemente, esta discusión ha tenido una particular argumentación tratándose de la indemnización derivada de los vicios redhibitorios, dado que se ha sostenido que como el deber precontractual de información se proyecta sobre el contenido del contrato y genera problemas de incumplimiento, es más adecuado atraer la indemnización del daño a la responsabilidad contractual, pues también se infringe un deber de prestación $^{136}$. Ciertamente tal razonamiento también podría aplicarse a los casos de inobservancia de una obligación de advertencia precontractual, deviniendo la pretensión indemnizatoria en contractual, restringiéndose en demasía la indemnización precontractual.

Sin embargo, a nuestro juicio, debe admitirse que el acreedor opte entre la indemnización precontractual y contractual, en atención a tres argumentos ${ }^{137}$. En primer lugar, si bien el daño se produce en el marco del contrato, en aquellos

\footnotetext{
134 UNIDROIT (2010), p. 113, extendiéndolo a casos de conflicto potencial con los remedios contractuales.

135 Tal regla se sustenta en la premisa que a la parte perjudicada le puede resultar más simple recurrir a los precontractuales, comunicando, por ejemplo, la anulación con base al error (LANDO y BEALE (2003), p. 413).

136 En tal sentido Morales (2010), pp. 90-91.

137 Hemos desarrollado los argumentos para sustentar la opción entre la tutela precontractual y contractual en LÓPEZ (2017b), pp. 69-77.
} 
casos en que ha existido una anomalía en su fase de formación, la tutela no se desplaza necesaria y automáticamente a la de incumplimiento, como lo revela aquella opinión según la cual la acción redhibitoria no tendría una naturaleza resolutoria, sino rescisoria o anulatoria ${ }^{138}$, ubicándose en sede precontractual y no en la contractual. Por otro lado, tratándose de los vicios redhibitorios el daño puede situarse en la etapa contractual, pero existe una infracción del deber precontractual de información, de modo que debería reconocerse el derecho al acreedor para optar entre la indemnización precontractual y contractual, elección que determinará la aplicación de uno u otro estatuto de responsabilidad. Finalmente, si concordáramos con aquella doctrina según la cual ambas indemnizaciones cubren el interés positivo y tienen idéntico plazo de prescripción, en realidad estaríamos ante la misma indemnización -cuya naturaleza sería contractual-, de modo que ni siquiera se presentaría un concurso.

Lo cierto es que no tendría mucho sentido que el legislador hubiera aludido en los artículos 1861, 1933, 2192 y 2203 a la indemnización contenida en los artículos 1553, 1555, 1556, 1558 y 1489, dado que, en tales casos, se hubiera remitido a las reglas generales, como lo hizo en el inciso primero del artículo 1999 a propósito del contrato de confección de obra material. A nuestro juicio, en las hipótesis previstas en el primer grupo de artículos que hemos referido ha querido regular una pretensión distinta: la indemnización precontractual, que podría transformarse en contractual como consecuencia del ejercicio del derecho de opción del acreedor, supuesto en el cual efectivamente existiría un concurso de pretensiones indemnizatorias, pues éstas serían distintas, evidenciando una zona de confluencia entre ambas.

$Y$ es que, como hemos consignado en otro $\operatorname{sitio}^{139}$, el derecho de opción es sucedáneo al derecho de crédito, de modo que no debe restringirse su ejercicio, porque equivaldría a desprotegerlo frente a lo que él estime que el derecho debe tutelarlo, esto es, ante la ineficacia o el incumplimiento. Por otra parte, tratándose de la infracción de deberes precontractuales de información derivados del error, no resulta fácil determinar cuál es el interés que debe tutelarse: no haber contratado de haber conocido la información verdadera u omitida o haberlo hecho con la información correcta ${ }^{140}$. Por lo mismo, parece más lógico reconocer, a quien ha contratado con información defectuosa, la facultad de elegir el interés en que quiera ser protegido, optando entre desligarse del contrato, a través de

138 Planteamiento sustentado por Guzmán (2007), pp. 99-101. Baraona (2008), pp. 665 y 669. Sustentando su naturaleza rescisoria propiamente tal LóPEz (2017a), pp. 443-453.

139 LÓPEZ (2015), pp. 107 y ss.

140 Basozabal (2009), p. 707. 
la nulidad acompañada de una indemnización precontractual o mantenerlo, demandando la indemnización contractual.

La relevancia práctica de escoger entre una pretensión indemnizatoria u otra radica en el estatuto jurídico aplicable, lo que no sólo incidirá en el alcance de los daños indemnizables, sino también en la presunción de culpa y el plazo de prescripción de la acción para reclamarla, toda vez que en nuestro ordenamiento jurídico resulta indiscutido que la indemnización precontractual se rige por las normas de la responsabilidad extracontractual, constatación que deviene en un argumento adicional para abogar por la opción del acreedor tratándose de la pretensión indemnizatoria.

\section{Conclusiones}

De lo expuesto en los párrafos precedentes es posible arribar a las siguientes conclusiones:

$1^{\circ}$ La indemnización de daños en sede precontractual es un medio de tutela que deriva de la infracción de los deberes precontractuales de lealtad e información que, por regla general comprende el interés negativo, y cuyo ejercicio es mayoritariamente complementario, admitiéndose excepcionalmente una indemnización autónoma con ocasión de la ruptura injustificada de las tratativas preliminares, la pérdida del derecho de alegar la nulidad y los vicios redhibitorios, si el acreedor así lo decide.

$2^{\circ}$ Tratándose de la infracción del deber de lealtad e información existen casos en que se advierte una confluencia entre la indemnización precontractual y contractual, debiendo reconocérsele al acreedor el derecho de optar por una u otra, esto es, facultándolo para reclamar los daños derivados de la no celebración del contrato o avanzar a la etapa contractual y solicitar aquellos ocasionados por el incumplimiento del contrato.

$3^{\circ}$ La sistematización de los supuestos en que se puede demandar la indemnización de daños en forma concurrente o autónoma, y la determinación de casos en que confluya la pretensión indemnizatoria precontractual y contractual, permitirá al acreedor diseñar de mejor forma su estrategia de protección. Si bien parece más conveniente inclinarse por la segunda, podrían existir dificultades para acreditar el alcance del daño derivado del incumplimiento, mas no aquél ocasionado por la ineficacia del contrato celebrado, hipótesis en la cual se justificaría optar por la indemnización precontractual.

\section{BiBLIOGRAFÍA CITADA}

Alessandri Rodríguez, Arturo, Somarriva Undurraga, Manuel, Vodanovic Haclicka, Antonio (2005): Tratado de Derecho Civil. Parte Preliminar y General. Tomo II (séptima edición, Santiago, Editorial Jurídica de Chile). 
Alonso Pérez, Mariano (1971): "La responsabilidad precontractual", en: Revista Crítica de Derecho Inmobiliario (485, No 2), pp. 859-922.

Alonso Pérez, María Teresa (2012): "La función de las obligaciones precontractuales de advertencia en la formación del contrato de servicios" (Estudio de Derecho Contractual Europeo), en: www.indret.com.

ARroyo I AmaYuelas, Esther (2003): "Formación y perfección del contrato", en: Cámara Lapuente, Sergio (coord.), Derecho Privado Europeo (Madrid, Editorial Colex), pp. 335-370.

AsúA GonzÁlez, Clara I. (1989): La culpa in contrahendo (tratamiento en el derecho alemán y presencia en otros ordenamientos) (Bilbao, Ediciones Universidad del País Vasco).

Asúa GonzÁlez, Clara, Hualde Sánchez, José Javier (2003): “Codificación de la culpa in contrahendo en el Derecho Alemán", en: Cabanillas Sánchez, Antonio (Coord.), Estudios Jurídicos en homenaje al profesor Luis Díez-Picazo. Tomo II. Derecho de Obligaciones (Madrid, Editorial Civitas) pp. 1415-1433.

Baraona González, Jorge (2012): La nulidad de los actos jurídicos: consideraciones históricas y dogmáticas (Bogotá, Editorial Pontificia Universidad Javeriana-lbáñez).

Banakas, Stathis (2009): Liability for Contractual Negotiations in English Law: Looking for the Litmus Test, en: www.indret.com.

Barrientos Zamorano, Marcelo (2008): Daños y deberes en las tratativas preliminares de un contrato (Santiago, Editorial LegalPublishing).

BarRientos Zamorano, Marcelo (2015a): "Nuevos deberes precontractuales de información en los certificados de cobertura provisorio, definitivo y la propuesta del contrato de seguro", en: Revista de Derecho Universidad Católica del Norte (Año 22, No 1), pp. 65-104.

BARRIENTOS ZamORANO, Marcelo (2015b): "El deber precontractual de información en el contrato de seguro, un producto financiero y de consumo: Estudio de sus fuentes" en: Revista Chilena de Derecho (Año 42, No 2), pp. 423-451.

BARros Bourie, Enrique (2006): Tratado de responsabilidad civil extracontractual (Santiago, Editorial Jurídica de Chile).

Barros Bourie, Enrique, Rojas Covarrubias, Nicolás (2010): "Responsabilidad por declaraciones y garantías contractuales", en: Departamento de Derecho Privado Universidad de Concepción (coords.), Estudios de Derecho Civil V (Santiago, Editorial Abeledo Perrot LegalPublishing), pp. 511-526.

Basozabal Arrué, Xabier (2009): "En torno a las obligaciones precontractuales de información", en: Anuario de Derecho Civil (62, № 2), pp. 647-712.

Beale, Hugo (2012): Mistake and non-disclosure of facts. Models for English Contract Law (Oxford, Oxford University Press). 
Beale, Hugo, Fauvarque, Cosson, Bénédicte, Rutgers, Jacobien, Tallon, Denis, Vogenauer, Stefan (2010): Cases, Materials and Text on Contract Law (segunda edición, Oxford, Hart Publishing).

BenatTI, Francesco (1963): La reponsabiità precontrattuale (Milano, Giuffrè).

Bernad, Mainar, Rafael (2015): "Responsabilidad ante la ruptura injustificada de los tratos preliminares", en: Revista Crítica de Derecho Inmobiliario (Año 91, No 747), pp. 11-50.

Bettı, Emilio (1969): "Teoría general de las obligaciones" (Madrid, Revista de Derecho Privado).

BOETSH Gillet, Cristián (2011): La buena fe contractual (Santiago, Editorial Jurídica de Chile).

Borda, Alejandro (2014): "La buena fe en la etapa precontractual", en: Revista Vniversitas (Año 129), pp. 39-79.

CABANILlas, Antonio (1995): "El ámbito de la responsabilidad precontractual o culpa in contrahendo", en: Revista Crítica de Derecho Inmobiliario (Año $\left.628, N^{\circ} 2\right)$, pp. 747-788.

Cabanillas Sánchez, Antonio (2000): Los deberes de protección del deudor en el derecho civil, en el mercantil y en el laboral (Madrid, Ediciones Civitas).

Cartwright, John (2007): Contract Law. An Introduction to the English Law of Contract for the Civil Lawyer (Oxford, Hart Publishing).

CARTWRIGHT, John, Hesselink, Martjin (2009): Precontractual liability in European Private Law (Oxford, Cambridge University Press).

CARuso, Daniela (1993): La culpa in contrahendo. L'esperienza statunitense e quella italiana (Milano, Giuffrè).

Celedón Förster, Rosario, Silberman Veszpremi, Patricia (2010): Responsabilidad precontractual por ruptura de negociaciones contractuales (Santiago, Editorial Jurídica de Chile).

Céspedes Proto, Rodrigo (2004): "El enriquecimiento sin causa en la jurisprudencia chilena", en: Revista Chilena de Derecho Privado (No 3), pp. 9-33.

Corral TalCIANI, Hernán (2010): Contratos y Daños por Incumplimiento (Santiago, Editorial AbeledoPerrot LegalPublishing).

Claro Solar, Luis (1979): Explicaciones de Derecho civil chileno y comparado. Volumen V. Tomo X: De las obligaciones II (reimpresión, Santiago, Editorial Jurídica de Chile).

De Cossío y Corral, Alfonso (1975): Instituciones de Derecho Civil 1. Parte General. Derecho de Obligaciones (Madrid, Alianza Editorial).

De Cossío y Corral, Alfonso (1955): "El dolo en el Derecho civil" (Madrid, Revista de Derecho Privado). 
De la Maza Gazmurı, Íñigo (2006): “El retiro unilateral como un caso de responsabilidad precontractual", en: De la Maza Gazmuri, ínigo (ed.), Cuaderno de Análisis Jurídico III (Santiago, Ediciones Universidad Diego Portales), pp. 131-158.

De la Maza Gazmurı, Íñigo (2008): "Buena fe, el reverso de la moneda. A propósito del dolo por omisión y el deber precontractual de informar", en: Revista Chilena de Derecho Privado ( $\left.N^{\circ} 11\right)$, pp. 43-72.

De la Maza Gazmurı, Íñigo (2010a): Los límites del deber precontractual de información (Madrid, Editorial Civitas-Thomson Reuters).

De la Maza Gazmuri, Íñigo (2010 b): "A propósito del artículo 1861", en: Departamento de Derecho Privado Universidad de Concepción (coord.), Estudios de Derecho Civil V (Santiago, Abeledo Perrot Legal Publishing), pp. 455-469.

De la Maza Gazmurı, Íñigo (2012a): "El error vicio del consentimiento: Entre la protección y el aprovechamiento", en: Elorriaga De Bonis, Fabián (coord.), Estudios de Derecho Civil VII (Santiago, Editorial Abeledo Perrot Legal Publishing), pp. 511-523.

De la Maza Gazmurı, Íñigo (2012b): "Configuración de la obligación de entregar a través de la autonomía privada: derechos de terceros", en: Revista de Derecho de la Pontificia Universidad Católica de Valparaíso (N 39), pp. 95-114.

De la MAZa Gazmurı, Íñigo (2014): "La tutela del comprador frente a la ausencia de calidades presupuestas en la cosa", en: Revista de Derecho de la Pontificia Universidad Católica de Valparaíso ( $\left.\mathrm{N}^{\circ} 43\right)$, pp. 117-159.

De la Maza Gazmurı, Íñigo (2015): "El error en los Principios Latinoamericanos de Derecho de los Contratos", en: Vaquer Aloy, Antoni, Bosch Capdevila, Esteve, Sánchez González, María Paz (eds.), El derecho común europeo de la compraventa y la modernización del derecho de contratos (Barcelona, Editorial Atelier), pp. 789-799.

De Los Mozos, José Luís (2005): "Responsabilidad en los "tratos preparatorios" del contrato", en: De Los Mozos, José Luis (coord.), Estudios sobre Derecho de Contratos, Integración Europea y Codificación (Madrid, Colegio de Registradores de la Propiedad y Mercantiles de España), pp. 165-186.

De Verda y Beamonte, José Ramón (2006): "Algunas reflexiones sobre el dolo como causa de invalidez del contrato y como fuente de responsabilidad precontractual", en: Centro de Estudios (editor), Libro homenaje al profesor Manuel Amorós Guardiola (Madrid, Colegio de Registradores de la Propiedad y Mercantiles de España), pp. 761-777.

Díez-PıCAzo, Luis (1964): "El contenido de la relación obligatoria", en: Anuario de Derecho Civil (17, № 2), pp. 346-366. 
Díez-Picazo, Luis, Roca Trías, Encarna, Morales Moreno, Antonio (2002): Los Principios del Derecho Europeo de Contratos (Madrid, Editorial Civitas).

Díez-PICAzo, Luis (2007): Fundamentos de Derecho Patrimonial I. Introducción a la Teoría del Contrato (sexta edición, Navarra, Editorial Civitas Thomson Reuters).

Díez-Picazo, Luis (2009): "La existencia del contrato", en: Anales de la Real Academia de Jurisprudencia y Legislación (N³9), pp. 177-194.

Domínguez Águila, Ramón, Domínguez Benavente, Ramón, Domínguez Hidalgo, Carmen (1998): "Comentario de jurisprudencia: Responsabilidad precontractual. Ruptura injustificada de negociaciones. Daños causados", en: Revista de Derecho Universidad de Concepción (Año 66, № 204), pp. 187-188.

Domínguez ÁGuILA, Ramón (2005): “Comentario de jurisprudencia: Responsabilidad precontractual. Principio de buena fe, aplicación del art. 1546 solo a la ejecución del contrato. Casación en el fondo por infracción de ley", en: Revista de Derecho Universidad de Concepción (Año 73, Nºs. 217-218), pp. 305-311.

Domínguez Águila, Ramón (2012): Teoría general del negocio jurídico, segunda edición (Santiago, Editorial Jurídica de Chile).

Duccl, Carlos (1988): Derecho Civil. Parte General, tercera edición (Santiago, Editorial Jurídica de Chile).

Fabre-Magnan, Muriel (1992): De l'obligation d'information dans les contrats. Essai d' une théorie (Paris, L.G.D.J.).

FAGGELLA, Gabrielle (1918): I periodi precontrattuali e la responsabilità precontrattuale, segunda edición (Roma, Stabilimento Tipografico della Società Cartiere Centrali).

Feno y Picón, Nieves (2017): "La revisión del tratamiento de la imposibilidad inicial y del error en los contratos, a través del análisis jurídico de diversos textos jurídicos", en: Anuario de Derecho Civil (70, № 2), pp. 473-785.

García Rubio, María Paz (1991): La responsabilidad precontractual en el derecho español (Madrid, Editorial Tecnos).

García Rubio, María Paz (2010): "La responsabilidad precontractual en la Propuesta de modernización del Derecho de Obligaciones y Contratos", en: Anuario de Derecho Civil (63, № 4), pp. 1621-1642.

García Rubio, María Paz, Otero Crespo, Marta (2010): "La responsabilidad precontractual en el derecho contractual europeo", en: www.indret.com.

García Rubio, María Paz (2012): "Perspectiva y prospectiva en tres casos de responsabilidad surgida en la etapa de negociación de un contrato", en: Bosch Capdevilla, Esteve (dir.), Nuevas perspectivas del derecho contractual (Barcelona, Editorial Bosch), pp. 261-289. 
GILIKER, Paula (2006): "Formation of Contract and Pre-contractual Information from an English Perspective", en: Grundmann, Stefan, Schauer, Martin (eds.), The architecture of European Codes and Contract Law (Alphen aan den Rjin, Kluwer Law International), pp. 301-319.

Gómez Calle, Esther (1994): "Los deberes precontractuales de información" (Madrid, La Ley).

Guzmán Brito, Alejandro (2002): "La buena fe en el Código Civil de Chile", en: Revista Chilena de Derecho (29, № 1), pp. 11-23.

GuZMÁn BRITO, Alejandro (2007): "Sobre la relación entre las acciones de saneamiento de los vicios redhibitorios y las acciones comunes de indemnización, con especial referencia a su prescripción", en: Revista Chilena de Derecho Privado (No 9), pp. 95-119.

Grundmann, Stefan (2006): "Structural elements in the Contract Law Parts of the German Civil Code", en: Grundmann, Stefan-Schauer, Martin (eds.), The architecture of European Codes and Contract Law (Alphen aan den Rjin, Kluwer Law International), pp. 57-81.

HeSSELINK, Martjin W. (2011): "The concept of Good Faith", en: Hartkamp, Arthur S. (ed.), Towards a European Civil Code (cuarta edición Alphen aan den Rijn, Kluwer Law Internacional Nijmegen, Ars Aequi Libri), pp. 619-649.

HILSENRAD, Arthur (1932). Las obligaciones precontractuales (trad. Faustino Menéndez Pidal), (Madrid, Editorial Góngora).

Hondius, Ewoud (1991): Precontractual Liability (Deventer, Kluwer Law internacional).

Jerez Delgado, Carmen (2011): La anulación del contrato (Madrid, Editorial Civitas).

Larenz, Karl (1958): "Derecho de Obligaciones. Tomo I." (Traducc. Jaime Santos Briz, Madrid, Editorial Revista de Derecho Privado).

Lando, Ole-Beale, Hugh (2003): Principios de derecho contractual europeo. Partes I y II (Traducc. Pilar Barres Benlloch, José Embid Irujo, Fernando Martínez Sanz, Madrid, Colegios Notariales de España).

León HuRTADO, Avelino (1991): La voluntad y la capacidad en los actos jurídicos (Santiago, Editorial Jurídica de Chile).

López Díaz, Patricia Verónica (2015): La autonomía de la indemnización de daños por incumplimiento de un contrato bilateral en el Código Civil Chileno (Santiago, Editorial Thomson Reuters Legal Publishing).

LÓPEz DíAz, Patricia Verónica (2016): "La indemnización de daños por vicios redhibitorios como medio de tutela precontractual autónomo en el Código Civil Chileno: un tópico cuya procedencia y alcance aún permanecen 
difusos" en: Barría Paredes, Manuel (coordinador), Estudios de Derecho Civil XI (Santiago, Editorial Thomson Reuters LegalPublishing), pp. 659-683.

López Díaz, Patricia Verónica (2017a): "La naturaleza jurídica de la acción redhibitoria en el Código Civil chileno: ¿Nulidad relativa, resolución por incumplimiento o rescisión propiamente tal?", en: Revista Chilena de Derecho (N 44, 2), pp. 423-459.

LÓPEz DíAz, Patricia Verónica (2017b): "La tutela precontractual y contractual del acreedor en el Código Civil chileno: dos sistemas estructuralmente diversos, pero ¿plenamente coherentes y convergentes?", en: Revista Chilena de Derecho Privado (№ 29), pp. 9-98.

LoRenzetTI, Ricardo Luis (2004): Tratado de los contratos. Parte General (Buenos Aires, Rubinzal Culzoni).

Manzanares, Alberto (1984): "La responsabilidad precontractual en la hipótesis de ruptura injustificada de las negociaciones preliminares", en: Anuario de Derecho Civil (37 № 3), pp. 687-748.

Manzanares Secades, Alberto (1985): "La naturaleza de la responsabilidad precontractual o culpa in contrahendo", en: Anuario de Derecho Civil (38, № 4), pp. 979-1010.

Martinic Galetovic, Dora, Reveco Urzúa, Ricardo (2005): "Acerca del error, su excusabilidad y otros tópicos" en: Varas Braun, Juan Andrés, Turner Saelzer, Susan (coords.), Estudios de Derecho Civil (Santiago, Lexis Nexis), pp. 259-296.

Medina Alcoz, María (2005): "La ruptura injustificada de los tratos preliminares: notas acerca de la naturaleza de la responsabilidad precontractual", en: Revista de Derecho Privado (89, № 3), pp. 104-105.

Monsalve Caballero, Vladimir (2008): "La buena fe como fundamento de los deberes precontractuales de conducta: una doctrina europea en construcción", en: Revista de Derecho, Universidad del Norte Barranquilla ( No $\left.^{\circ} 30\right)$, pp. 32-40,

Morales Moreno, Antonio Manuel (1982): "El dolo como criterio de imputación de responsabilidad al vendedor por los defectos de la cosa", en: Anuario de Derecho Civil (35 № 3), pp. 591-684.

Morales Moreno, Antonio Manuel (1988): El error en los contratos (Madrid, Editorial Ceura).

Morales Moreno, Antonio Manuel (2003): "Validez del Contrato", en: Cámara Lapuente, Sergio (coord.), Derecho Privado Europeo (Madrid, Editorial Colex), pp. 371-398.

Morales Moreno, Antonio Manuel (2010). Incumplimiento del contrato y lucro cesante (Navarra, Editorial Civitas). 
Morales Moreno, Antonio Manuel (2011): “¿Es posible construir un sistema precontractual de remedios? Reflexiones sobre la Propuesta de Modernización del Derecho de Obligaciones y Contratos en el marco del Derecho europeo", en: Albiez Dohrmann, Klaus Jochen (director), Palazón Garrido, María Luisa, Méndez Serrano, María del Mar (coords.), Derecho Privado Europeo y Modernización del Derecho Contractual en España (Barcelona, Editorial Atelier), pp. 400-422.

Morales Moreno, Antonio Manuel (2014): "Los Principios latinoamericanos de derecho de los contratos. Un debate abierto sobre grandes cuestiones jurídicas de la contratación", en: Anuario de Derecho Civil (67, № 1), pp. 227-254.

NúÑez Carrera, David (2007): "Declaraciones y silencios en el ámbito precontractual", en: Corral Talciani, Hernán, Rodríguez Pinto, María Sara (coords.), Estudios de Derecho Civil II (Santiago, Editorial Lexis Nexis), pp. 323-344.

OVIEDO AlBÁN, Jorge (2014): "Indemnización de perjuicios por vicios redhibitorios en el Código Civil chileno-colombiano", en: Revista Pontificia Universidad Javeriana (No 129), pp. 242-267.

PANTALÉ́N, Fernando (2011): "Responsabilidad precontractual: propuestas de regulación para un futuro Código Latinoamericano de Contratos", en: Anuario de Derecho Civil (64, №3), pp. 897-929.

Peñallillo Arévalo, Daniel (1996): "El enriquecimiento sin causa. Principio de derecho y fuente de obligaciones", en: Revista de Derecho Universidad de Concepción (Año 64, № 200), pp. 7-40.

Pinochet Olave, Ruperto, Concha Machuca, Ricardo (2015): "Las prestaciones mutuas en caso de nulidad de contrato: carácter indemnizatorio o restitutorio en el derecho civil chileno", en: Revista de Derecho Privado Universidad Externado de Colombia (№ 28), pp. 129-152.

Prado López, Pamela (2015a): La colaboración del acreedor en los contratos civiles (Santiago, Editorial Thomson Reuters La Ley).

Prado López, Pamela (2015b): “El dolo incidental": ¿Una manifestación del dolo contractual?", en: Vidal Olivares, Álvaro, Severin Fuster, Gonzalo, Mejías Alonzo, Claudia (eds.), Estudios de Derecho Civil X (Santiago, Editorial Thomson Reuters, La Ley), pp. 725-737.

QuesadA SÁnchez, Antonio José (2011): "Las negociaciones dirigidas a la formación del contrato", en: Albiez Dohrmann, Klaus Jochen (dir.), Palazón Garrido, María Luisa, Méndez Serrano, María del Mar (coords.), Derecho Privado Europeo y Modernización del Derecho Contractual en España (Barcelona, Editorial Atelier), pp. 55-107. 
Rémy-Corlay, Pauline (2006): "Structural Elements of French Civil Code", en: Grundmann, Stefan, Schauer, Martin (eds.), The architecture of European Codes and Contract Law (Alphen aan den Rjin, Kluwer Law International), pp. 33-55.

Ríos Ossa, Roberto (2014): El deber precontractual de declaración del riesgo en el seguro de daños (Santiago, Editorial Legal Publishing Thomson Reuters).

Rivero Hernández, Francisco (2006): "Responsabilidad del falsus procurator por no ratificación del contrato celebrado sin poder", en: Anuario de Derecho Civil (59, № 3), pp. 989-1063.

Rodríguez Grez, Pablo (1995): Inexistencia y nulidad en el Código Civil. Teoría Bimembre de la Nulidad (Santiago, Editorial Jurídica de Chile).

Rodríguez PINTO, María Sara (2013): "Responsabilidad precontractual en la Ley № 19.496 de 1997 sobre Protección de los Derechos de los Consumidores", en: Domínguez Hidalgo, Carmen, González Castillo, Joel, Barrientos Zamorano, Marcelo, Goldenberg Serrano, Juan (coords.), Estudios de Derecho Civil VIII (Santiago, Editorial Legal Publishing), pp. 493-501.

Rodríguez Grez, Pablo (2011): Nuevas tendencias de la responsabilidad (Santiago, Editorial Abeledo Perrot Legal Publishing).

Rojo AJurIA, Luis (1994): El dolo en los contratos (Madrid, Editorial Civitas).

Roppo, Vincenzo (2006): "Formation of contract and Pre-contractual Information from an Italian perspective (Final Remarks from the Perspective of European Contract Law)", en: Grundmann, Stefan, Schauer, Martin (eds.), The architecture of European Codes and Contract Law (Alphen aan den Rjin, Kluwer Law International), pp. 283-299.

Rosende Álvarez, Hugo (1979): Algunas consideraciones sobre la responsabilidad precontractual (Valparaíso, Ediciones Universitarias de Valparaíso).

Saleilles, M.R (1907): "De La Responsabilité Précontractuelle. A propos d’ un étude nouvelle sur la matière", en: Revue Trimestrielle de Droit Civil $\left(\mathrm{N}^{\circ} 6\right)$, pp. 697-751,

San Martín Neira, Lilian (2013): "Responsabilidad precontractual por ruptura injustificada de negociaciones. Corte Suprema, rol 1872/2010", en: Revista Chilena de Derecho (Año 40, № 1), pp. 317-324.

San Martín Neira, Lilian (2015): "La teoría de la inexistencia y su falta de cabida en el Código Civil Chileno", en: Revista Chilena de Derecho (Año 42 № 3), pp. 745-784.

SAPONE, Natalino (2008): La responsabilità precontrattuale (Milano, Giuffrè).

Segura Riveiro, Francisco (2007): "El interés indemnizable en las hipótesis de responsabilidad precontractual", en: Corral Talciani, Hernán, Rodríguez 
Pinto, María Sara, Estudios de Derecho Civil II (Santiago, Editorial Lexis Nexis), pp. 345-362.

Schulze, Reiner (2006). "Deberes precontractuales y conclusión del contrato en el derecho contractual europeo", en: Anuario de Derecho Civil (59, № 1), pp. 29-58.

Storme, Mathias (2003): "Good faith and contents of contracts in European Private Law", en: Espiau Espiau, Santiago, Vaquer Aloy, Antoni (coords.), Bases de un Derecho Contractual Europeo (Valencia, Editorial Tirant lo Blanch), pp. 21-30.

StitChKIn BRANOver, David (2008): El mandato civil, quinta edición actualizada (Santiago, Editorial Jurídica de Chile).

Tomás Martínez, Gema (2010): “Naturaleza de la responsabilidad precontracual (culpa in contrahendo) en la armonización jurídica europea", en: Revista de Derecho Universidad Católica del Norte (Año 17, № 1), pp. 193-207.

VAN ERP, J.H.M. (2011): "The precontractual stage", en: Hartkamp, Arthur (editor), Towards a European Civil Code (cuarta edición, Alphen aan den Rijn, Kluwer Law Internacional Nijmegen, Ars Aequi Libri, 2011), pp. 493-513.

Unidroit, Instituto Internacional para la Unificación del Derecho Privado, Principios Unidroit sobre los contratos comerciales internacionales (Roma, 2010). Versión española dirigida por Alejandro A.M. Garro (Madrid, Ediciones Unidroit).

Viguri Perea, Agustín (2003): "Análisis de derecho comparado sobre la culpa in contrahendo", en: Espiau Espiau, Santiago, Vaquer Aloy, Antoni (Coords.) Bases de un Derecho Contractual Europeo (Valencia, Editorial Tirant lo Blanch), pp. 79-88.

VISINTINI, Giovanna (1972): La reticenza nella formatione dei contratti (Padova, Cedam).

Vivanco Luengo, Pablo (2008): "Aspectos relevantes de la responsabilidad precontractual por ruptura injustificada de las negociaciones precontractuales", en: Revista de Derecho Universidad Católica de la Santísima Concepción (No 17), pp. 139-150.

VON IHERING, Rudolf (2005): Della culpa in contrahendo ossia del risarcimento del danno nei contratti nulli o non giunti a perfezione (traducción italiana de F. Procchi, Napoli, Jovene Editore).

Zuloaga Ríos, Isabel Margarita (2006): Teoría de la responsabilidad precontractual. Aplicaciones en la formación del consentimiento de los contratos (Santiago, Editorial Lexis Nexis). 
